\title{
FOMC Announcements and Predictable Returns
}

\author{
by \\ Mihail Velikov \\ Submitted in Partial Fulfillment of the \\ Requirements for the Degree \\ Doctor of Philosophy \\ Supervised by \\ Professor Robert Novy-Marx \\ Business Administration \\ Simon School of Business \\ University of Rochester \\ Rochester, New York
}

2015 


\section{Dedication}

I would like to dedicate this dissertation to my beautiful, loving, and caring wife, Delina Agnosteva, and to my always encouraging parents Anna Velikova and Zhelez Velikov. Without their support, I would not have made it this far. 


\section{Biographical Sketch}

Mihail Velikov was born in Varna, Bulgaria on August 4, 1987. He attended Ramapo College, where he obtained Bachelor of Science degrees in Mathematics and Business Administration with a concentration in Finance. In the summer of 2010, he enrolled in the doctoral program of the Simon Business School at the University of Rochester. $\mathrm{He}$ was awarded a doctoral student fellowship from 2010 to 2014 and earned a Master of Science in Business Administration from Simon in 2013. Mihail's research in empirical asset pricing was conducted under the supervision of Professor Robert Novy-Marx. 


\section{Acknowledgments}

I am deeply indebted to my advisor Robert Novy-Marx for his continued guidance, encouragement, and support. I am also very grateful to my committee members, Bill Schwert and Rob Ready, for their invaluable comments and timely suggestions on many drafts of this study. My committee members' tutelage has shaped the way I think about financial economics and is certain to guide my research going forward. I would also like to express my gratitude to my colleagues Anisha Barbora, Mike Dambra, Jacquelyn Gillete, Matt Gustafson, Hongtao Li, Egor Matveyev, Jordan Moore, Rob Parham, Yufeng Wu, and Hao Zou for their great comments, constructive criticism, and encouragement. Special thanks also go to Simon faculty members Ron Kaniel, John Long, Cliff Smith, Jerry Warner, and Toni Whited for their teaching, comments, and suggestions. 


\section{Abstract}

Existing literature associates FOMC meetings with abnormally high market returns and good performance of the CAPM. I show that both effects are concentrated on meetings with surprise cuts to the Fed funds target rate. Moreover, stocks that perform poorly around meetings with surprise rate cuts subsequently outperform the market. This behavior generates robust predictability in the cross section of monthly stock returns. Stocks whose returns have positive covariances with surprise changes to the Fed funds target rate carry a significant premium in their future returns. These covariances, however, are transient, indicating short-lived interest rate exposure for individual firms. The evidence is difficult to reconcile with equilibrium risk pricing of short-term interest rate shocks in the cross section of stock returns. 


\section{Contributors and Funding Sources}

The work in this dissertation has been conducted independently without outside funding support, under the supervision of Professors Robert Novy-Marx, Bill Schwert, and Rob Ready of the department of Finance. Graduate study was supported by a doctoral student fellowship from the Simon Business School. 


\section{Table of Contents}

Dedication $\quad$ ii

Biographical Sketch iii

Acknowledgments $\quad$ iv

$\begin{array}{ll}\text { Abstract } & \text { v }\end{array}$

Contributors and Funding Sources $\quad$ vi

List of Tables $\quad$ ix

List of Figures $\quad$ x

1 Introduction 1

2 Stock returns around FOMC meetings 6

2.1 Aggregate market returns on FOMC meeting days . . . . . . . . . . . 7

2.2 CAPM performance on FOMC meeting days . . . . . . . . . . . 9

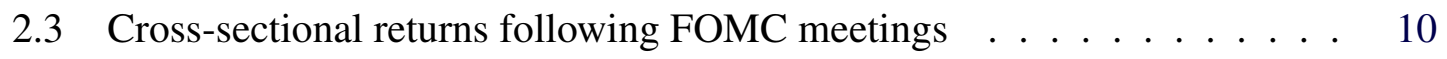


3 Monetary policy risk and the cross section 12

3.1 Measuring monthly monetary policy shocks . . . . . . . . . . . . 12

3.2 Cross-sectional return predictability $\ldots \ldots \ldots$

3.3 Robustness of the monthly trading strategy . . . . . . . . . . . . 18

3.4 Monetary policy shock exposure . . . . . . . . . . . . . 21

3.5 The link to FOMC Meeting announcements . . . . . . . . . . . 23

4 Implications for theory $\quad 26$

4.1 Funding liquidity . . . . . . . . . . . . . 26

4.2 Money-in-utility . . . . . . . . . . . . . . . 28

4.3 Cash-flow duration ....................... 29

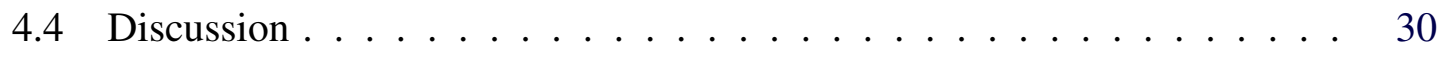

5 Conclusion $\quad 32$

$\begin{array}{ll}\text { Bibliography } & 33\end{array}$ 


\section{List of Tables}

1 Market excess returns on FOMC days . . . . . . . . . . . . . . . . 38

2 CAPM performance on FOMC days vs. non-FOMC days . . . . . . . . 39

3 Daily trading strategy based on surprise FOMC rate cuts . . . . . . . . 40

4 Descriptive statistics for monthly monetary policy proxies _ . . . . . . 41

5 Monetary policy shocks and the cross section . . . . . . . . . . 42

6 Alphas and five-factor loadings of $\beta_{\% \Delta r_{\text {LIBOR IM }}}$-sorted portfolios $\ldots \ldots 43$

7 Double sorts .......................... 44

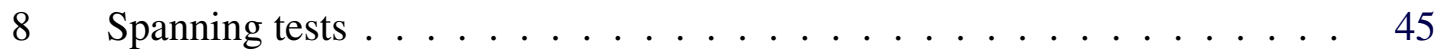

9 Fama-MacBeth regressions . . . . . . . . . . . . . 46

10 Robustness ......................... 47

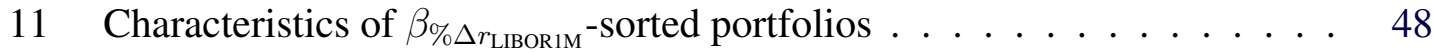

12 The link to Fed announcements . . . . . . . . . . . . . . . . . . 49 


\section{List of Figures}

1 Market excess returns on FOMC days $\ldots \ldots \ldots \ldots$

2 CAPM performance on FOMC days vs. non-FOMC days . . . . . . . 51

3 Returns to $\beta_{\% \Delta r_{\text {LBORIM }} \text { strategy by year } \ldots \ldots \ldots \ldots \ldots \ldots \ldots \ldots} \ldots \ldots \ldots$

4 Event-time monthly portfolio returns . . . . . . . . . . . . . . 53

5 Event-time monthly portfolio returns for the highest $\beta_{\% \Delta r_{\text {LIBORIM }}}$ portfolio . 54

6 Event-time monthly portfolio returns excluding surprise rate cuts . . . . 55 


\section{Introduction}

The financial crisis of 2007-2008 and the unprecedented response by the Federal Reserve have spurred renewed interest in studying the effect of monetary policy on the stock market. There are now a number of puzzling findings related to the Fed's influence on asset prices. Savor and Wilson (2013) report that over 60\% of the equity premium since 1958 is earned on days with scheduled Federal Open Market Committee (FOMC) meetings, inflation or unemployment announcements. Similarly, Savor and Wilson (2014) show the Capital Asset Pricing Model (CAPM) prices assets surprisingly well on such days, but it fails on all other days. Lucca and Moench (2014) document that since 1994 over $80 \%$ of the equity premium is earned in the 24 hours prior to scheduled FOMC meeting announcements. Taken together, these results are difficult to reconcile with standard asset pricing theory.

This paper studies the asset pricing implications of information released in macroeconomic news announcements. I focus on FOMC meetings between 1989 and 2008, for which Kuttner (2001) develops estimates of unanticipated changes to the Fed funds target rate. I document two important findings. First, I show the high market returns and the good CAPM performance on scheduled FOMC meeting days are strongly concentrated on 
meetings with surprise rate cuts. I also document that stocks that react negatively to surprise rate cuts subsequently outperform the market, which generates robust predictability in the cross section of monthly stock returns.

Why are these results important? The extant literature concludes that the high average market returns on scheduled macroeconomic announcement days are independent of the news released on those days. However, I find that average excess market returns on days with no surprises and on days with surprise rate hikes are not significantly different from other non-announcement days. This result highlights an asymmetric investor response to the news contained in FOMC announcements. In the spirit of the Diamond and Rajan (2011) "government put" hypothesis, one interpretation of this finding is that the market responds favorably only to surprise rate cuts because investors update their beliefs about the Federal Reserve's commitment to ease monetary policy following adverse shocks to the economy.

My cross-sectional results have broad implications for the way investors price monetary policy risk. ${ }^{1}$ I document that cross-sectional variation in stocks' responses to surprise rate cuts predicts future returns. This relation holds even at a monthly frequency. Since monthly returns are commonly used in asset pricing studies, this predictability can lead to misleading conclusions. To test whether monetary policy risk is priced in the cross section of stock returns, in the spirit of the Merton (1973) Intertemporal Capital Asset Pricing Model (ICAPM), one can form tradable portfolios by sorting on individual stock returns' covariances with monetary policy shocks, and then examine the future returns of these portfolios. Proxies for surprise changes to the Fed funds target rate in the macroe-

\footnotetext{
${ }^{1}$ I use monetary policy shocks and surprise changes to the Fed funds target rate interchangeably. Woodford (2001) argues that starting in the late 1980s, the primary tool for conducting monetary policy by the Fed is targeting the overnight Fed funds rate.This is not possible after the recent financial crisis, when the Fed funds target rate reached the zero lower bound, which is why most of the analysis to follow focuses on the 1986 - 2008 period.
} 
conomics literature include changes to the Fed funds futures rate, 1-month USD LIBOR rate, or 1-month USD LIBOR futures rate. ${ }^{2}$ Stocks with returns that covary positively with these proxies earn a significant premium going forward. The premium is not explained by other popular anomalies, it exists across industries and among large caps, and it holds for various definitions of monetary policy shocks. Long-short trading strategies designed to exploit this effect earn annualized returns of up to $16 \%$ with a Sharpe ratio of 0.82 .

Given this result, it is tempting to conclude that monetary policy risk is priced in the cross section of stock returns. A closer look at the evidence, however, indicates that this is not the case. The long portfolio, consisting of stocks that covary positively with surprise Fed funds rate changes, is responsible for all of the strategy returns. Specifically, the predictability of the returns to this portfolio comes from stocks that react negatively to FOMC meeting announcements of surprise rate cuts and subsequently outperform the market.

Moreover, firms' exposure to monetary policy shocks is transient. Beta estimates from consecutive, non-overlapping periods are uncorrelated. Accounting characteristics potentially linked to interest rate exposure through firms' financing or investment decisions, such as leverage, operating leverage, investment, and net income, are not statistically significantly different across portfolios either. The only characteristic that increases monotonically across portfolios is the Amihud (2002) illiquidity measure.

These results paint an interesting picture of the cross-sectional behavior of stock returns around FOMC meetings in which the Fed unexpectedly lowers rates. The market treats this event as a positive signal and earns positive returns. A certain subset of stocks, however, responds negatively to these announcements, but they earn higher returns going forward. These stocks tend to be less liquid, but they are not significantly different from the rest of the market based on accounting characteristics associated with interest rate ex-

\footnotetext{
${ }^{2}$ Section 3.1 discusses the rationale for focusing on these measures in particular.
} 
posure. This suggests that the effect is caused by investor response to monetary policy shocks, as opposed to changes in firm production or financing decisions.

The evidence is difficult to reconcile with an ICAPM equilibrium in which monetary policy risk is a priced factor. One alternative behavioral explanation is that the covariances I use to form portfolios capture noise trading. Suppose there are fundamental investors and noise traders. If surprise cuts correspond to good information, then all fundamental investors buy, some noise traders buy, and some noise traders sell. Further, the noise traders can only impact the prices of the illiquid stocks. The result is undervaluation and subsequent outperformance of stocks that are sold on days in which the Fed unexpectedly cuts rates.

This study contributes to the literature in several ways. First, it adds to the growing literature on asset price behavior around days of scheduled macroeconomic announcements. In addition to the previously mentioned papers, Cieslak et al. (2014) document a weekly cyclicality for the aggregate market returns following FOMC meetings. I contribute to this literature by extending the results in Savor and Wilson $(2013,2014)$ and by documenting a new finding regarding the cross-sectional behavior of stock returns following FOMC meetings.

Second, I add to an extensive literature on the responsiveness of realized asset returns to macroeconomic shocks. The literature goes back at least to Schwert (1981) and more recent examples include Bernanke and Kuttner (2005), Gürkayana et al. (2007), and Maio (2014). ${ }^{3}$ I contribute to this literature by documenting the impact of stock return sensitivities to monetary policy shocks on the cross section of expected returns.

Third, the monthly cross-sectional findings in this paper are orthogonal to the 23 anomalies in Novy-Marx and Velikov (2014). Even though the recent literature is skeptical

\footnotetext{
${ }^{3}$ Savor and Wilson (2013) and Maio (2014) contain excellent literature reviews.
} 
of new anomalies, the long-short strategies in this study are all value-weighted and robust to many different specifications. The premium is driven by Fed announcement days, reducing the likelihood that it is spurious. Moreover, the return predictability is achieved by a sort on covariances as opposed to firm characteristics. This is noteworthy, since covariances are noisy and hard to estimate. ${ }^{4}$

Lastly, this paper also sheds light on the empirical validity of several different classes of theoretical models. The direction of return predictability I document is inconsistent with theoretical models featuring financial intermediaries as the representative agent and those featuring a representative agent who derives utility from holding real money balances. ${ }^{5}$ Both classes of models imply a negative price of risk for funding liquidity in the first group and short-term interest rates in the second. To the extent that unanticipated changes in the Fed funds target rate affect funding liquidity or short-term interest rates, my findings suggest that the price of risk for both factors is positive. ${ }^{6}$ Moreover, the strong mean reversion of firms' monetary policy shock exposure is difficult to reconcile even with models that predict a positive price of risk, such as those linking expected returns to cash-flow duration. $^{7}$

\footnotetext{
${ }^{4}$ As a comparison, a decile sort on betas with the returns to the Fama and French HML factor for the same period yields an insignificant average return to the long-short portfolio of 6 bps per month with a t-stat of 0.13 .

${ }^{5}$ See He and Krishnamurthy (2013), Brunnermeier and Sannikov (2014), Brunnermeier and Pedersen (2009), Geanakopoulos (2009), Adrian and Boyarchenko (2012), Adrian et al. (2014), and Drechsler et al. (2014) for examples of the first group and Chan et al. (1996), Balvers and Huang (2009), Gu and Huang (2012), and Lioui and Maio (2014) for examples of the second.

${ }^{6}$ Drechsler et al. (2014) explicitly make the connection between monetary policy and funding liquidity. They provide a dynamic asset pricing model linking equity risk premia to monetary policy through the funding liquidity channel. In their setup, a central bank varies the nominal interest rate in order to regulate the effective risk aversion of the marginal investor in the economy. It does so by influencing financial institutions' cost of leverage. Lowering the nominal interest rate reduces the cost of leverage, which increases risk taking and in turn decreases risk premia.

${ }^{7}$ For example, Menzly et al. (2004), Santos and Veronesi (2006) and Lettau and Wachter (2007).
} 


\section{Stock returns around FOMC meetings}

This section revisits the evidence in Savor and Wilson $(2013,2014)$ by examining how the information contained in scheduled announcements of macroeconomics news affects asset prices. Kuttner (2001) documents days in which there are Federal Open Market Committee (FOMC) meetings and measures the nature of the surprise changes to the Fed funds target rate using Fed funds futures. He identifies 177 FOMC meeting days between 06/1989 and 06/2008, of which 56 are scheduled meetings with surprise cuts, 43 are scheduled meetings with surprise hikes, 54 days are scheduled meetings with no surprise actions, and 24 are unscheduled meetings ( 2 with surprise hikes and 22 with surprise cuts). ${ }^{1}$ I examine whether the results documented in Savor and Wilson $(2013,2014)$ depend on the information released in the announcements. Throughout the rest of the paper, I refer to these FOMC announcement days as FOMC days.

\footnotetext{
${ }^{1}$ The updated list is available on his website: http://econ.williams.edu/people/knk1/research
} 


\subsection{Aggregate market returns on FOMC meeting days}

Figure 1 shows a scatter plot of the excess returns to the CRSP value-weighted portfolio against the estimated surprise changes to the Fed funds target rate for the 177 FOMC days, splitting them into scheduled meetings with surprise cuts, scheduled meetings with no surprises, scheduled meetings with surprise hikes, and unscheduled FOMC meetings. The market returns tend to be positive only for days with negative surprise changes to the Fed funds target. In other words, these are meetings in which the Fed officials either eased monetary policy, or they did not tighten it as much as the market expected they would. On the other hand, for days with no surprises or with surprise hikes, the average market excess returns are approximately zero.

Table 1 evaluates the statistical significance of the patterns in Figure 1. The table reports results from time-series regressions of daily market excess returns on a constant and indicators for different types of FOMC days. The first specification closely resembles the result documented in Savor and Wilson (2013). On days with scheduled FOMC meetings, the market excess returns are 20 basis points higher than on all other days. Breaking the scheduled meetings into meetings with surprise hikes, no surprise actions, and surprise cuts, however, reveals similar patterns to the ones observed in Figure 1 (specifications (2) - (4)). On the 56 days with surprise cuts, the market excess return was 42 basis points higher than on all other days. For the other scheduled meetings, the excess market returns are not statistically significantly different than non-FOMC days. On days with unscheduled FOMC meetings, the market has average excess returns that are 34 basis points higher than on all other days, although the statistical significance is somewhat weaker, primarily because of the small number of these days. This is consistent with the results for the sur-

prise cuts in specification (4), since 22 out of the 24 unscheduled meetings had surprise cuts. 
The results in Table 1 extend the evidence documented by Savor and Wilson (2013) and Lucca and Moench (2014). In both studies, the authors examine whether the information contained in announcements affects the market returns on FOMC days by controlling for the surprises in time-series regressions of the market returns on indicators for FOMC days. They document insignificant slopes for the surprises and conclude that the market reaction on FOMC days is independent of the news released by the announcement. Figure 1 shows that the relation between the two variables is not linear. Nevertheless, the average excess returns to the market on FOMC days with no surprises or with surprise hikes are not reliably different from the returns on other days. This result is difficult to reconcile with the interpretation in Savor and Wilson (2013) that the observed effect is compensation for bearing increased uncertainty risk on days with scheduled macroeconomic announcements. Instead, it seems to support a "government put" explanation (e.g. Diamond and Rajan (2011)), in which on surprise cuts investors update their beliefs about the Federal Reserve's commitment to ease monetary policy in response to adverse shocks to the economy. An alternative interpretation would be that the higher market returns on FOMC meeting days with surprise rate cuts represent a wealth transfer. If stock investors own a "government put" through implicit insurance against adverse economic shocks by the Federal Reserve, then the abnormal market returns on these days equal the value that is transfered from the Fed to stock investors from exercising this put option.

The link between my results and the pre-FOMC drift, documented by Lucca and Moench (2014), however, is more subtle. Using intraday returns, they document that on average, the S\&P 500 performs well in the 24-hour window prior to FOMC meetings. ${ }^{2}$ In contrast, I look at the close-to-close returns on the announcement days. On one hand, the pre-FOMC drift could be concentrated on meetings with surprise cuts, which is consistent

\footnotetext{
${ }^{2}$ The announcements are released consistently at approximately $2: 15 \mathrm{pm}$. They look at the $2 \mathrm{pm}-2 \mathrm{pm}$ return.
} 
with both a "government put" explanation and information leakage. On the other hand, it could be that the pre-FOMC drift occurs before all meetings and the market reacts symmetrically following the announcements, that is having higher returns on cuts and lower returns on hikes. My paper does not distinguish between the two explanations.

\subsection{CAPM performance on FOMC meeting days}

Figure 2 extends the evidence in Savor and Wilson (2014) of the good CAPM performance on scheduled macroeconomic announcement days. The top panel replicates their results, showing that the CAPM prices the ten beta portfolios well on days with scheduled FOMC meetings, but it fails on all other days. In the bottom panel, FOMC days are split into surprise cuts, no surprises, and surprise hikes. Similar to the aggregate market returns, the good CAPM performance holds only for FOMC days with surprise cuts. This result is consistent with the evidence in Section 2.1. Higher return spreads are expected on days with large moves in the market. Given that the aggregate market returns on days with no surprises or with surprise hikes are not significantly different than on other days, it is not surprising then that the CAPM does not price assets on such days.

Table 2 evaluates the statistical significance of the results documented in Figure 2. Panel A documents the realized portfolio betas, estimated using the full sample. Panel B documents average returns for different types of days for the ten portfolios, as well as for a portfolio that is long stocks in the high beta portfolio and short stocks in the low beta portfolio. There is a statistically significant spread in the returns between the high and low beta portfolios on FOMC days, which is consistent with the results in Savor and Wilson (2014). The table also shows that this result is entirely concentrated on days with

surprise cuts to the Fed funds rate. The spread between the returns of the high and low 
beta portfolios on days with surprise cuts is 81 basis points, with a t-stat of 3.46. The corresponding return spread (t-stat) for meetings with no surprises or surprise hikes are 4 basis points (0.17) and 11 basis points (0.24), respectively.

\subsection{Cross-sectional returns following FOMC meetings}

Sections 2.1 and 2.2 reveal that FOMC days with surprise cuts to the Fed funds target are characterized by high average market returns and good pricing performance of the CAPM. Even though the market as a whole performs well on those days there is a subset of stocks that perform poorly. A natural question is whether these stocks are systematically different, either in their characteristics or in their future returns. Table 3 examines the 78 days with surprise cuts to the Fed funds target rate (56 scheduled and 22 unscheduled FOMC meetings). For each meeting, three-day cumulative abnormal returns (CARs) are calculated for all firms. Five portfolios are formed based on firms' average 3-day CARs using NYSE breakpoints. Stocks are held either for a month and a half (31 trading days) or until another surprise cut occurs. The 31 trading days correspond to the average number of days between scheduled meetings ( 8 per year).

The average daily returns for the five portfolios and for a portfolio long stocks with the lowest 3-day CARs and short stocks with the highest 3-day CARs are reported in Panel A. This strategy generates significant profits, with average daily returns of 5.07 basis points with a t-stat of 3.12, resulting in an annualized Sharpe ratio of 0.72. Panel B documents average characteristics of the five portfolios. Not surprisingly, the portfolios with more extreme reactions, $(\mathrm{L})$ and $(\mathrm{H})$, exhibit high CAPM $\beta$ 's, since they contain more volatile stocks. What is interesting to note, however, is that the stocks in portfolio $(\mathrm{L})$ are more thinly traded compared to stocks in portfolio $(\mathrm{H})$. Moreover, they exhibit higher relative 
bid-ask spreads and illiquidity measures. This implies that the stocks that are sold on FOMC days and outperform the market going forward are less liquid. 


\section{3 . Monetary policy risk and the cross section}

The difference between the performance of the portfolios examined in Section 2.3 following surprise cuts to the Fed funds rate has broad implications for the impact of monetary policy on the cross section of stock returns. I show that stocks whose returns covary positively with short-term interest rate changes, estimated on monthly horizons, carry a significant premium in their future stock returns. This predictability stems primarily from firms that perform poorly around FOMC meetings with surprise rate cuts and outperform the market going forward.

\subsection{Measuring monthly monetary policy shocks}

The identification of monetary policy shocks is itself subject to a substantial literature in macroeconomics. They are hard to identify, especially at a consistent frequency, for example at the monthly frequency typically employed in asset pricing studies. From the late 1980's until the recent financial crisis, the Federal Reserve has conducted monetary policy primarily by targeting the overnight Fed funds rate through open-market operations. ${ }^{1}$

\footnotetext{
${ }^{1}$ See Woodford (2001).
} 
I survey the macroeconomics literature for proxies of unanticipated changes in the Fed funds target rate.

Patelis (1997), Thorbecke (1997), Goto and Valkanov (2002), and Maio (2014) use changes in the target or effective Fed funds rate. Cochrane and Piazzesi (2002) use changes in Eurodollar rates, while Rigobon and Sack (2003) propose using the Eurodollar futures. Kuttner (2001) advocates using Fed funds rate futures. Gürkayana et al. (2007) compare the forecasting performance of the four measures discussed so far, including also the shortterm Treasury bill rate and the commercial paper rate, and they find that Fed funds rate futures predict target funds rate changes best at the 1-6 month horizons. They find that Treasuries and commercial paper have lower forecasting power and reconcile this with the convenience yield embedded in these two instruments, which reflects their perceived safety and high liquidity. Building on this literature, Bernanke and Kuttner (2005) also use Fed funds rate futures at a monthly frequency and document a strong negative contemporaneous correlation between monthly monetary policy shocks and aggregate stock market returns. Thus, to measure the sensitivity of stocks to monetary policy surprises, I use monthly changes and percent changes of the Fed funds rate futures, the 1-month Eurodollar rate, and the 1-month Eurodollar futures. The changes and percent changes are calculated as differences or percent differences between the daily rates at the end of two successive months.

Gürkayana et al. (2007) emphasize that changes in the effective Fed funds rate are not a good measure for the effects of Fed actions on the stock market, because this rate is directly controlled by the Fed and it does not properly gauge the unanticipated actions of the monetary authority. Unlike the Fed funds rate, the other three proxies are market-set and forward-looking. Thus, changes in those measures more accurately reflect surprises in Fed actions. This is best illustrated by an example. If the market expects the Fed to 
increase rates, the Fed funds futures rate would be higher than the Fed funds rate. If, however, the Fed does not act and the rates remain unchanged, it is a surprise that would be reflected in the futures prices, but not in the effective rate. Thus, as I confirm later, the effective Fed funds rate is different from the other three measures and is ill-suited for studying the impact of Fed actions on the stock market.

\subsubsection{Data}

Data on the effective Fed funds rate series come from the H.15 release by the Federal Reserve Board. It is available on a daily basis from the Federal Reserve Economic Data (FRED) database of the St. Louis Fed from 07/1954 onwards (series DFF). As a measure of the Eurodollar rate, I use the 1-month USD London Interbank Offer Rate (LIBOR). The data on the LIBOR series used in this study again come from from the FRED database, which reports LIBOR rates on a daily basis (series USD1MTD156N), starting in 01/1986.

The data on futures contracts come from Datastream. Datastream provides daily price quotes on Fed funds rate and Eurodollar futures contracts settled at the end of the following month. The Fed funds rate futures are traded on the Chicago Board of Trade (CBOT) while the Eurodollar futures are traded on the Chicago Merchantile Exchange (CME). The underlying unit for the federal funds futures is a contract with a face value of $\$ 5,000,000$ for one month, calculated on a 30-day basis at a rate equal to the average overnight Fed funds rate for the contract month. Similarly, the underlying unit for the Eurodollar contracts is a Eurodollar interbank deposit having approximately \$1 million principal value, for one- or three-month term to maturity, for spot settlement on the 3rd Wednesday of the contract month. The final settlement uses the LIBOR rate of the respective maturity. The implied futures rate equals 100 minus the quoted daily settlement prices. The data are available on a daily basis starting in 10/1988 for the Fed funds futures (series CFFCS00) 
and in 04/1990 for the Eurodollar futures (series IEMCS00).

\subsubsection{Descriptive statistics}

Table 4 provides descriptive statistics for the monthly measures of monetary policy surprises used in this study. Panel A looks at changes in the shocks, and Panel B at percent changes in the shocks. We can observe that on average, the shocks are fairly similar, decreasing by approximately 2.5 basis points per month. The effective Fed funds rate proxy, however, seems to be a lot more volatile. In both panels it exhibits the lowest correlations with the rest of the proxies. In Panel A, the average correlation between changes in the effective Fed funds rate and the other proxies is only $31 \%$, and the corresponding value for Panel B is $34 \%$.

In this context, it is not surprising that the proxies based on the LIBOR rate and the ones based on futures prices seem to be highly correlated. Further, the LIBOR rate is easily obtainable and has a longer history than the proxies based on the futures. The data start in 1986 as opposed to 1988 for the Fed funds futures and in 1990 for the LIBOR futures.

These results confirm the work of Gürkayana et al. (2007) and Kuttner (2001), who argue that changes in LIBOR and the two futures rates are better gauges of the unanticipated policy actions than changes in the effective Fed funds rate. The forward-looking nature of the market-based measures allows them to incorporate the expected Fed actions and to more cleanly identify surprises. Thus, I don't use the effective Fed funds rate in the analysis. 


\subsection{Cross-sectional return predictability}

To test whether monetary policy risk is priced in the cross section of stock returns in the spirit of the Merton (1973) ICAPM, one can form portfolios based on sorts on historical estimates of stocks' exposure to monetary policy shocks, and examine whether they have different future returns. As noted in Section 3.1, I proxy for monetary policy shocks using monthly changes or percent changes in the Fed funds futures rate, 1-month USD LIBOR, or 1-month USD LIBOR futures rate.

Table 5 documents the results. In each month, firms are split into two groups based on the sign of their beta with respect to monetary policy shocks. The betas are estimated using rolling 60 months of data. Average excess returns are reported for trading strategies that are long stocks with positive betas and short stocks with negative betas for different samples.

Except for the strategies executed in the universe of financial firms, the rest generate average returns that are statistically significantly positive. For example, across the nonfinancials, firms whose returns covary positively with percent changes in the Fed funds futures rate earn average returns that are 55 bp higher than stocks which covary negatively with percent changes in the Fed funds futures rate. The t-statistic on this strategy is 2.93, which is close to the threshold of 3.00 proposed by Harvey et al. (2014). The results are economically significant, especially given that this is just a sample split and does not yet fully exploit the signal by splitting assets on each side into multiple portfolios.

The last three columns of the table show that the results are also present across industries. Instead of stocks, industry portfolios are split into two groups based on the sign of their beta with respect to changes in monetary policy. The table reports results for three different industry classifications: Fama and French 49 industries, 2-digit SIC codes, and 3-digit SIC codes. The results are consistent with the findings for individual firms. For ex- 
ample, 2-digit SIC code industry portfolios, whose returns covary positively with changes in the 1-month USD LIBOR rate earn on average 39 bp more than industries which covary negatively with those changes.

This result implies that there is a premium to be earned by holding stocks whose returns covary with unexpected monetary policy shocks. This finding, by itself, is consistent with the conclusion that monetary policy risk is priced in the cross section of stock returns with a positive price of risk. That is, stocks that pay off when the Fed tightens monetary policy (i.e., when there is an unanticipated increase in the Fed funds target rate) are riskier. Likewise, stocks that pay off when the Fed cuts rates unexpectedly are hedges and command lower expected returns. The evidence in Sections 3.4 and 3.5, however, is difficult to reconcile with an equilibrium risk-hedging explanation.

Table 6 reports results of a more refined sort on the sample of nonfinancial firms. It uses firms' covariances with percent changes in the one-month USD LIBOR rate $\left(\beta_{\% \triangle r_{L I B O R I M}}\right)$ as a proxy for monetary policy shock exposure. ${ }^{2}$ The positive and negative $\beta_{\% \triangle r_{L I B O R 1 M}}$ portfolios are further split into three, resulting in a total of six portfolios. Panel A demonstrates there is a significant spread in the returns between portfolios $(\mathrm{H})$ and $(\mathrm{L})$, leading to an average monthly return of $0.81 \%$ for the long-short strategy. This is equivalent to an annualized return of approximately $10 \%$ with a Sharpe ratio of about 0.68 , nearly double the Sharpe ratio of the market. Surprisingly, none of the standard pricing models account for this effect. This strategy generates an alpha of $0.65 \%$ per month, with a t-stat of 2.28 , even after controlling for all five factors.

Interestingly, the premium is generated mostly from the high beta portfolio. A strategy that is long stocks in portfolio (H) and short stocks in portfolios (3) and (4) earns 70bp per month with a t-stat of 2.53 , while a strategy that is long stocks in portfolio (3) and

\footnotetext{
${ }^{2}$ The $\beta_{\% \triangle r_{L I B O R 1 M}}$ proxy is chosen because of the longer LIBOR sample, but the results are even slightly stronger for the proxies based on futures data.
} 
(4) and short stocks in portfolio (L) earns $11 \mathrm{bp}$ with an insignificant t-stat of 0.51 . This observation makes the interpretation of the premium as evidence of a priced risk factor more difficult, since it seems to be concentrated only in one portfolio.

Panel B reports the loadings from the time-series regressions of the portfolio returns on the five-factor model. Only the SMB and LIQ loadings of the long-short portfolio are significantly different from zero. It is worth emphasizing, however, that the significant loading of the $(\mathrm{H})-(\mathrm{L})$ portfolio on the LIQ factor derives mainly from the $(\mathrm{H})$ portfolio, which has a loading of 0.18 on LIQ with a t-stat of 3.24. This result indicates that the stocks in portfolio $(\mathrm{H})$, which drive most of the observed premium, are significantly exposed to aggregate liquidity risk. None of the other portfolios have significant loadings on the LIQ factor.

\subsection{Robustness of the monthly trading strategy}

The premium I document in Section 3.2 is a robust feature of the data. Using double sorts, spanning tests, and Fama-MacBeth regressions, I next show that this effect is orthogonal to the 23 anomalies from Novy-Marx and Velikov (2014). Moreover, it is not driven by a few good years and it is not sensitive to the proxy used for sorting, the strategy construction, or the horizon used for beta estimation. In fact, sorting stocks into deciles based on their covariances with percent changes in the 1-month USD LIBOR futures rate and forming a long-short portfolio yields an annualized return of $16.2 \%$ with a Sharpe ratio of 0.82 .

\subsubsection{Time series of strategy returns}

Figure 3 plots the returns to the long-short portfolio from Table 6 by year. The result is not driven by a few particularly good years, since the strategy earned more than $10 \%$ in 
eleven out of the twenty-two years. Moreover, the strategy does not exhibit particularly bad years, which explains its high Sharpe ratio. The worst performing year is 2000, when it lost $8.33 \%$.

\subsubsection{Double sorts}

To ensure that the result is not driven by other effects in the cross section of stock returns, I next perform a battery of robustness tests. First, I show that the premium is not a different anomaly in disguise. To this end, Table 7 reports average excess returns and alphas for conditional $\beta_{\% \triangle r_{L I B O R 1 M}}$ strategies, constructed from double-sorts on $\beta_{\% \triangle r_{L I B O R 1 M}}$ and each of the 23 anomaly signals from Novy-Marx and Velikov (2014). In each month, all nonfinancial firms in the CRSP/COMPUSTAT merged database with 60 months of returns are sorted into terciles based on one of the 23 signals. Then, within each tercile, stocks are sorted into deciles based on their $\beta_{\% \Delta r_{L I B O R 1 M}}$. The $\beta_{\% \triangle r_{L I B O R}}$ 's are estimated using the previous 60 months of data from the following regression: $R_{t}^{e}=$ $\alpha+\beta_{\% \Delta r_{L I B O R}} \% \Delta r_{L I B O R, t}+\varepsilon_{t}$, where $\% \Delta r_{L I B O R}$ is the monthly percent change in the one-month USD LIBOR yield. The strategies are long all stocks in the top $\beta_{\% \triangle r_{L I B O R 1 M}}$ deciles and short all stocks in the bottom $\beta_{\% \Delta r_{L I B O R 1 M}}$ deciles, across all terciles. NYSE breakpoints are used for the sorts. Panel A presents average excess returns, while Panels B, C, and D report CAPM, Fama and French 3-factor model, and Fama and French 4-factor model alphas, respectively. We can observe that the $\beta_{\% \Delta r_{L I B O R 1 M}}$ strategies earn significantly positive returns on average, conditioning on any of the signals. 


\subsubsection{Spanning tests}

Table 8 reports average excess returns and spanning tests between the strategy examined in Table 6 and the 23 anomalies from Novy-Marx and Velikov (2014). Of the 23 anomalies, only about half of them have average returns that are statistically significantly different from zero over this period. Moreover, only three strategies have marginally higher average returns and only two have a marginally higher t-stat than the strategy based on monetary policy shock sensitivities. The spanning tests also reveal that the strategy from Table 6 has a positive and highly statistically significant information ratio relative to all of the 23 anomalies separately. In untabulated results, I find that the strategy has a significant information ratio even when benchmarked against all 23 anomalies simultaneously.

\subsubsection{Fama-MacBeth regressions}

Table 9 documents results from Fama-MacBeth regressions of the form $r_{t j}=\beta^{\prime} \mathbf{x}_{t j}+$ $\varepsilon_{t j}$, where $\mathbf{x}_{t j}$ includes their betas with respect to $\% \Delta r_{L I B O R 1 M}$ and other characteristics known to predict returns. The sensitivity to LIBOR changes has strong cross-sectional power in predicting returns, as evidenced by the positive and significant coefficient on $\beta_{\% \triangle r_{L I B O R 1 M}}$. Moreover, it is robust to the inclusion of size, value, gross-profitability, standardized unexpected surprises, asset growth, and momentum.

\subsubsection{Robustness to construction, horizon, and measurement}

Table 10 demonstrates that the results are also robust to using different proxies, as well as to using different sorting schemes (quintiles vs deciles, New York Stock Exchange Breakpoints or not) and various estimation periods for $\beta_{\% \triangle r_{L I B O R 1 M}}$. The results indicate that the documented premium is not sensitive to the measures used for construction, as 
almost all strategies earn statistically significantly positive average returns. Moreover, using percent changes in the LIBOR futures proxy in a decile sort yields annualized returns of approximately $16 \%$ with a Sharpe ratio of 0.82 . Using only two or three years for the beta estimation somewhat weakens the results, but they are still positive and mostly significant for the decile sorts.

\subsection{Monetary policy shock exposure}

To investigate the drivers behind the premium documented in the previous two sections table 11 reports average characteristics for the six portfolios from Table 6. Panel A shows that, on average, $62 \%$ of the nonfinancial firms have negative point estimates for their betas with respect to percent changes in LIBOR. This is consistent with Bernanke and Kuttner (2005), who report that on average the market returns are negatively correlated with surprise changes to the Fed funds target. Not surprisingly, the firms in the tails are relatively small, having average market capitalizations of approximately $\$ 1.33$ and $\$ 1.14$ billion for the low and high portfolios, respectively.

The time-series behavior of the estimated betas used for sorting, however, is puzzling. By construction, the sorting betas exhibit a sizable spread on average, ranging from -0.54 for the low portfolio to 0.45 for high portfolio. However, looking at 60-month lags or leads of the sorting betas, which use non-overlapping time periods for estimation, reveals no persistence in the estimated betas. Both the lags and the leads are indistinguishable between the six portfolios, ranging between -0.09 and -0.08 for the lags and between 0.05 and -0.10 for the leads. Thus, beyond the mechanically induced persistence from the rolling beta estimation, firms' exposure to monetary policy shocks appears to be transient. Further, the realized portfolio betas with respect to LIBOR changes do not follow the pat- 
tern observed in the sorting ones. The low portfolio has a point estimate for its $\beta_{\%} \Delta r_{\text {LIBORIM }}$ of -0.05 . The corresponding number for the high portfolio is -0.11 . This result implies strong mean-reversion in firms' exposure to monetary policy, which in turn implies that firms are not fundamentally exposed to surprise short-term interest rate changes. It is difficult to reconcile the documented premium with an equilibrium risk-hedging explanation of short-term interest rate shocks.

Panel B investigates firm characteristics that could be related to firms' short-term interest rate exposure, such as book-to-market, net income, leverage, operating leverage, and investment. Only book-to-market is monotonically increasing in the portfolios. The value effect, however, does not account for the premium, as evidenced by the significant alphas of the long-short portfolio in Table 6 and the insignificant loading on the HML factor. None of the other characteristics are statistically significantly different across the portfolios, which is not surprising since most of these are persistent, unlike the betas used for sorting.

Panel C documents average characteristics related to firms' stock prices, as opposed to their accounting numbers. There does not seem to be a discernible pattern in the average percentage of institutional holdings across the portfolios. On the other hand, there is a U-shaped relation in the average idiosyncratic volatility across the portfolios, which is not surprising. Firms with extreme stock price sensitivities to any variable are expected to have higher volatility. Of greater interest, the Amihud (2002) illiquidity measure is monotonically increasing across the portfolios. The high portfolio has an average illiquidity that is roughly twice the corresponding average for the low portfolio. This is consistent with the the result in Table 6, where only the high portfolio has a significant loading on the Pastor and Stambaugh (2003) liquidity factor.

Figure 4 examines the behavior of the stocks in the six portfolios from Table 6 pre- 
and post-portfolio formation. It plots cumulative average returns in event time for the six portfolios individually (top panel) and for the portfolio that is long stocks in portfolio six and short stocks in portfolio one (bottom panel). Time zero is the portfolio formation period. Stocks in the high portfolio significantly underperform the rest of the market prior to portfolio formation. That is, at any point in time, firms with returns that were highly positively correlated with changes in LIBOR in the last 60 months earned lower average returns in that same time period. Moreover, these stocks perform better post-portfolio formation. This is consistent with the evidence in Table 6, which shows that the premium is driven by high $\beta_{\% \Delta r_{\text {LIBORIM }}}$ stocks.

\subsection{The link to FOMC Meeting announcements}

Sections 3.2 and 3.4 establish that the premium in the monthly strategy is driven by high $\beta_{\% \Delta r_{\text {LIBORIM }}}$ stocks that underperform prior to portfolio formation and outperform post-

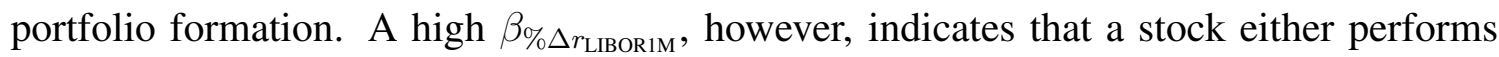
well when LIBOR goes up or performs poorly when LIBOR goes down. To decipher which of these two explanations is driving the underperformance observed in Figure 4, Figure 5 splits the high portfolio into two portfolios, based on a difference in ranks in sorts on $\beta_{\% \Delta r_{\text {LIBOR IM }}^{+}}^{+}$and $\beta_{\% \Delta r_{\text {LIBOR IM }}}^{-} \cdot \beta_{\% \Delta r_{\text {LIBOR IM }}}^{+}$and $\beta_{\% \Delta r_{\text {LIBOR IM }}}^{-}$are estimated similar to $\beta_{\% \Delta r_{\text {LIBORIM }}}$, except using positive and negative LIBOR changes, respectively. $\left(H^{+}\right)$denotes the portfolio consisting of firms in portfolio $(\mathrm{H})$ that have relatively high $\beta_{\% \Delta r_{\mathrm{LIBOR} I \mathrm{M}}}^{+}$, while $\left(H^{-}\right)$denotes the portfolio consisting of firms in portfolio $(\mathrm{H})$ that have relatively

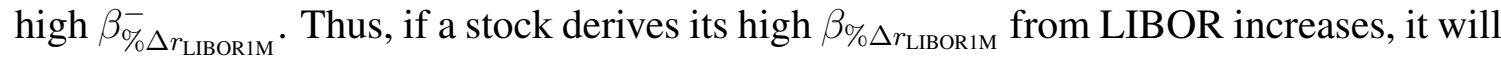
be in $\left(H^{+}\right)$. If it derives its high $\beta_{\% \Delta r_{\text {LIBORIM }}}$ from LIBOR decreases, it will be in $\left(H^{-}\right)$.

The entire effect of the underperformance in figure 4 is concentrated in the stocks 
whose high beta was due to negative changes in LIBOR, which is consistent with the pattern in the daily returns observed in Section 2.3. Stocks that perform poorly in months when the Fed lowers rates unexpectedly (i.e. months in which LIBOR goes down) tend to outperform the market going forward. Given the infrequent nature of large changes in short-term interest rates, it is reasonable that most of the undervaluation in Figures 4 and 5 prior to portfolio formation occurs on FOMC meetings with surprise cuts.

Figure 6 repeats the analysis in Figure 4 by excluding FOMC days in the estimation of the average returns. It uses the portfolios from Table 6, but excludes the 3 days around each of the 78 days with surprise rate cuts for calculating the cumulative average returns. The underperformance of portfolio $(\mathrm{H})$ in the 60 months prior to portfolio formation from Figure 4 is nonexistent in Figure 6, implying that the undervaluation of the high $\beta_{\% \Delta r_{\text {LIBORIM }}}$ stocks occurs on FOMC meetings with surprise cuts.

Table 12 investigates how the profitability of the monthly strategies is affected when we exclude FOMC days for the $\beta_{\% \Delta r_{\text {LIBOR IM }}}$ estimation. Panel A reports results for four different trading strategies for the February 1991 - June 2008 period using monthly returns cumulated from the daily CRSP tape. For this panel, FOMC days are not excluded. All strategies earn statistically significantly positive returns, even after over 5 years of the sample is cut.

In Panel B, the analysis in Panel A is repeated, but the 3 days around the 177 FOMC days are excluded. That is, the returns for all stocks and the percent change in LIBOR in the 3 days surrounding the announcements are set to zero. The betas are re-estimated and the trading strategies are formed on the re-estimated betas. In Panels C, D, and E, announcements with surprise hikes, no surprise changes, and surprise cuts respectively, are excluded. This tests whether these days are random. If the FOMC days are not driving the monthly results, then there should be no change in the statistical significance of the 
strategies. Interestingly, Panel B shows that treating the 177 days as nonexistent reduces the significance of the strategies to zero. For example, the decile strategy employing NYSE breakpoints decreases from earning $0.77 \%$ per month on average with a t-statistic of 2.41 in Panel A to an insignificant $0.14 \%$ with a t-statistic of 0.50 . This suggests that Fed announcement days drive the premium documented in Section 3.2.

Panels $\mathrm{C}$ and $\mathrm{D}$ reveal that days with positive rate surprises or no surprises do not influence the strategies. The decile strategy based on NYSE breakpoints earns statistically significant $0.61 \%$ in Panel C and $0.68 \%$ in Panel D. Excluding the days with surprise cuts, however, eliminates the profitability of the strategies. This confirms that the underpricing observed in Figures 4 and 5 is driven by days in which the Fed decides either not to raise interest rates, when the market expected a raise, or when the Fed lowers the rates more than what the market expected. Stocks that underperform on those days are sorted into portfolio $(\mathrm{H})$ in Table 6 and earn statistically significantly higher returns than the rest of the market subsequently.

These results paint an interesting picture of the cross-sectional behavior of stock returns around FOMC meetings with surprise rate cuts. When the Fed lowers rates unexpectedly, the market treats this as a positive signal and earns positive returns. A certain subset of stocks, however, responds negatively to these shocks, yet earn higher returns going forward. These stocks tend to be less liquid, but they are not significantly different from the rest of the market based on accounting characteristics that can be linked to firms' interest rate exposure. This suggests that the effect is caused by investors' response to monetary policy shocks, as opposed to changes in firms' production or financing decisions. 


\section{4 . Implications for theory}

My results are difficult to reconcile with equilibrium pricing of monetary policy risk. Thus, I argue that they have implications for several different classes of theoretical models. The first type, which I refer to as funding liquidity models, focuses on financial intermediaries as the representative agent in the economy, and their funding liquidity in particular. The second type of models feature the "money-in-utility" framework. According to these models, money balances enter directly into the utility function of the representative agent, causing monetary policy surprises to affect the stochastic discount factor. Finally, I survey a third class of models based on cash-flow duration, since they have been used to explain popular asset pricing anomalies such as the value premium.

\subsection{Funding liquidity}

Since the recent financial crisis a growing number of papers incorporate macroeconomic models of financial frictions such as Bernanke and Gertler (1989) and Kiyotaki and Moore (1997) to study asset pricing. The central theme of that literature is that the marginal investor is likely a financial intermediary, so the stochastic discount factor should depend 
on the health of the financial sector, or funding liquidity. Thus, assets that pay off in times of high marginal value of wealth, i.e. times with low funding liquidity, should be less risky. These papers differ in the proxy they use for times of high marginal value of wealth. ${ }^{1}$ Empirically, Adrian et al. (2014) show that a single-factor model consisting of security broker-dealers' leverage achieves an $R^{2}$ of $77 \%$ in quarterly tests of the size, value, momentum, and treasury portfolios.

In this context, Drechsler et al. (2014) provide a dynamic asset pricing model linking equity risk premia to monetary policy precisely through the funding liquidity channel. In their setup, a central bank varies the nominal interest rate in order to regulate the effective risk aversion of the marginal investor in the economy. It does so by influencing financial institutions' cost of leverage. Lowering the nominal interest rate reduces the cost of leverage and effectively reduces the external finance premium, increasing risk taking and, in turn, decreasing risk premia. Thus, the implications are similar to those stemming from the funding liquidity literature, where stocks that pay off when funding liquidity increases (rates go down) should be riskier. To the extent that short-term interest shocks affect funding liquidity in the direction suggested by Drechsler et al. (2014), the results presented in Section 3.2 indicate that the price of risk is positive. Moreover, it is difficult to reconcile the prediction of this class of models with the transitory nature of stock returns' exposure to monetary policy surprises.

\footnotetext{
${ }^{1}$ For example, He and Krishnamurthy (2013) and Brunnermeier and Sannikov (2014) argue that it is the equity of financial intermediaries while Brunnermeier and Pedersen (2009), Geanakopoulos (2009), and Adrian and Boyarchenko (2012) feature intermediary leverage as the relevant state variable.
} 


\subsection{Money-in-utility}

An emerging literature features a different channel linking monetary policy and short-term rates to the cross section of stock returns. For example, Lioui and Maio (2014) propose a generalized long-run risk model (e.g. Bansal and Yaron (2004)) that features the "moneyin-utility framework" (MUIF). ${ }^{2}$ In their setup, the representative agent derives utility from both consumption and real money balances. The authors derive a linearized stochastic discount factor that depends on the growth of the nominal interest rate in addition to the market return and consumption growth. Using changes in the effective Fed funds rate as a proxy for changes in interest rates, they show that their model has additional explanatory power in pricing size, value, and long-run reversal portfolios compared to the regular Capital Asset Pricing Model (CAPM) and the Consumption Capital Asset Pricing Model (CCAPM).

The authors derive an expression for the price of interest rate risk, where the sign depends entirely on the coefficient of relative risk aversion (CRRA). In their framework, a CRRA coefficient larger than one yields a negative price of risk. Thus, assets that pay off when the Fed tightens monetary policy should, according to these models, earn lower expected returns. The authors interpret this result as evidence that periods of tightening monetary policy are characterized by high inflation expectations and tight liquidity. In this context, my results present a challenge for this class of models, especially since the mapping between their predictions and my tests is fairly close. I show that, in the data, the direction of predictability is the opposite of the one hypothesized. Moreover, this class of models cannot account for the transitory nature of firms' monetary policy exposure either.

\footnotetext{
${ }^{2}$ Other papers that feature similar models are Chan et al. (1996), Balvers and Huang (2009), and Gu and Huang (2012)
} 


\subsection{Cash-flow duration}

Lastly, another strand of literature attempts to link variation in expected returns to firms' underlying cash-flow dynamics. Building on the return decomposition into cash flows and discount rate components by Campbell and Mei (1993), Cornell (1999) argues that growth firms may have high betas because of their cash-flow duration, even if the risk of their cash flows is mainly idiosyncratic. More recently, building on Menzly et al. (2004), Santos and Veronesi (2006) and Lettau and Wachter (2007) examine the effects of cross-sectional dispersion in cash-flow duration on expected returns and find that low duration assets have higher expected returns. The authors interpret their results as a theoretical justification of the value premium. In order to generate such predictions, however, both studies assume that shocks to discount rates are not priced. More recently, Santos and Veronesi (2010) argue that in the presence of discount rate shocks, the dispersion in cross-sectional cash-flow risk across firms necessary to generate the value premium is implausible. Nevertheless, the main predictions of these models with respect to short-term rates imply a negative relation between cash-flow duration and expected returns. The traditional measure for duration of fixed income securities is the Macaulay duration:

$$
D=\frac{\sum_{t=1}^{T} \frac{C F_{t}}{(1+y)^{t}}}{P}
$$

where $C F_{t}$ denotes the cash flow at time t, $y$ denotes the yield to maturity, and $P$ denotes the security price. This measure expresses the weighted-average time to maturity of the cash flows. What it represents, however, is the bond price's sensitivity to changes in the yield, since

$$
\frac{\partial P}{\partial y}=P \times \frac{D}{1+r} \Delta r \Rightarrow \frac{\Delta P}{P} \approx-\frac{D}{1+r} \Delta r
$$


The expression $D /(1+r)$ is referred to as "modified duration" and has a fairly intuitive application to firm equity pricing. Given data on a firm's stock returns and a short-term interest rate, the modified duration can be estimated through an ordinary least squares regression of the type $\frac{\Delta P_{t}}{P_{t}}=\alpha+\beta \Delta r_{t}+\varepsilon_{t}$, where $\beta \approx-\frac{D}{1+r}$. According to the abovementioned theory, if low cash-flow duration stocks are riskier due to their exposure to cash flow shocks, firms whose returns have higher betas with respect to changes in interest rates should have higher expected returns. These theories, however, are silent as to what interest rate is the appropriate one to use and typically do not feature a monetary authority that impacts short-term rates. However, if the Fed has some control over interest rates and the duration effect exists, then unanticipated monetary policy actions should affect the cross section of expected returns.

The direction of return predictability that I document is consistent with this class of models. However, the strong mean-reversion of monetary policy shock betas is more difficult to reconcile. Intuitively, cash-flow duration should be fairly persistent. Indeed, these models are primarily used to explain the value premium, but firms' book-to-market is more persistent than the betas that I use for sorting.

\subsection{Discussion}

The results documented in this study have broad implications for the impact of monetary policy on the cross section of stock returns. Theoretical models claiming that monetary policy shocks are priced in the cross section of equities have to account for the transitory nature of firms' exposure to interest rate changes and the resulting return predictability, both of which stem from stocks' behavior around FOMC meetings. Moreover, it is unclear why an investor would not be better off hedging monetary policy risk in futures markets 
as opposed to the cross section of equities. In efficient capital markets, any estimate of the price of risk of monetary policy surprises in the cross section of equities should roughly equal the returns to Fed funds or LIBOR futures.

Given that existing theoretical models cannot explain the return predictability that I document, it is interesting to investigate what explains it. The evidence suggests that it is not due to equilibrium risk-hedging. Instead, it appears to be driven by a particular type of investor behavior around FOMC meetings. One alternative behavioral explanation is that the covariances I use to form portfolios capture noise trading. Suppose there are fundamental investors and noise traders. If surprise cuts correspond to good information, then all fundamental investors buy, some noise traders buy, and some noise traders sell. Further, the noise traders can only impact the prices of the illiquid stocks. The result is undervaluation and subsequent outperformance of stocks that are sold on days in which the Fed unexpectedly cuts rates. 


\section{Conclusion}

This paper documents two new important findings regarding stock return behavior around FOMC meetings. First, it shows the high average returns to the market and the good pricing performance of the CAPM are concentrated on FOMC meetings in which there were surprise cuts to the Fed funds target rate. Second, it documents robust predictability in the cross section of stock returns stemming from stocks' response to surprise cuts to the Fed funds target rate.

3They paint an interesting picture of the behavior of stock returns around FOMC meetings with surprise cuts. When the Fed lowers rates unexpectedly, the market treats this as a positive signal and earns positive returns. A certain subset of stocks in the market, however, respond negatively to these shocks, but earn higher returns subsequently. These stocks tend to be less liquid, but they are not significantly different from the rest of the market based on accounting characteristics that can be linked to firms' interest rate exposure. This suggests the effect is caused by investors' response to monetary policy shocks, as opposed to changes in firms' production or financing decisions. This evidence is difficult to reconcile with equilibrium pricing in an ICAPM sense of monetary policy risk. 


\section{Bibliography}

Adrian, T., Boyarchenko, N. 2012. Intermediary leverage cycles and financial stability. Working paper.

Adrian, T., Etula, E., Muir, T. 2014. Financial intermediaries and the cross-section of asset returns. Journal of Finance, Forthcoming.

Amihud, Y. 2002. Illiquidity and stock returns: Cross-section and time-series effects. Journal of Financial Markets, 5, 31-56.

Ang, A., Hodrick, R. J., Xing, Y., Zhang, X. 2006. The cross-section of volatility and expected returns. Journal of Finance, 61, 259-299.

Balvers, R., Huang, D. 2009. Money and the (C)CAPM. Journal of Financial and Quantitative Analysis, 44, 337-368.

Bansal, R., Yaron, A. 2004. Risks for the long run: A potential resolution of asset pricing puzzles. Journal of Finance, 59, 1481-1510.

Bernanke, B., Gertler, M. 1989. Agency costs, net worth, and business fluctuations. American Economic Review, 79, 14-31.

Bernanke, B., Kuttner, K. 2005. What explains the stock market's reaction to Federal Reserve policy? Journal of Finance, 60, 1221-1257. 
Brunnermeier, M., Pedersen, L. H. 2009. Market liquidity and funding liquidity. Review of Financial Studies, 22, 2201-2238.

Brunnermeier, M., Sannikov, Y. 2014. A macroeconomic model with a financial sector. American Economic Review, Forthcoming.

Campbell, J. Y., Mei, J. 1993. Where do betas come from? Asset price dynamics and the sources of systematic risk. Review of Financial Studies, 6, 567-592.

Carhart, M. M. 1997. On the persistence in mutual fund performance. Journal of Finance, $52,57-82$.

Chan, K., Foresi, S., Lang, L. 1996. Does money explain asset returns? Theory and empirical analysis. Journal of Finance, 51, 345-361.

Cieslak, A., Morse, A., Vissing-Jorgensen, A. 2014. Stock returns over the FOMC cycle. Working paper.

Cochrane, J. H., Piazzesi, M. 2002. The Fed and interest rates: A high-frequency identification. American Economic Review, 92, 90-95.

Cornell, B. 1999. Risk, duration, and capital budgeting: New evidence on some old questions. Journal of Business, 72, 183-200.

Diamond, D., Rajan, R. 2011. Illiquid banks, financial stability, and interest rate policy. Working Paper 16994, National Bureau of Economic Research.

Drechsler, I., Savov, A., Schnabl, P. 2014. A model of monetary policy and risk premia. Working paper.

Fama, E. F., French, K. R. 1993. Common risk factors in the returns on stocks and bonds. Journal of Financial Economics, 33, 3-56. 
Geanakopoulos, J. 2009. The leverage cycle. NBER Macroeconomics Annual, 24, 1-65.

Goto, S., Valkanov, R. 2002. The Fed's effect on excess returns and inflation is bigger than you think. Unpublished Working Paper.

Gu, L., Huang, D. 2012. Consumption, money, intratemporal substitution and crosssectional asset returns. Working paper.

Gürkayana, R., Sack, B., Swanson, E. 2007. Market-based measures of monetary policy expectations. Journal of Business and Economic Statistics, 25, 201-212.

Harvey, C., Liu, Y., Zhu, H. 2014. ... and the cross-section of expected returns. Working Paper.

He, Z., Krishnamurthy, A. 2013. Intermediary asset pricing. American Economic Review, $103,732-760$.

Kiyotaki, N., Moore, J. 1997. Credit cycles. Journal of Political Economy, 105, 211-248.

Kuttner, K. 2001. Monetary policy surprises and interest rates: Evidence from the Fed funds futures market. Journal of Monetary Economics, 47, 523-544.

Lettau, M., Wachter, J. 2007. Why is long-horizon equity less risky? A duration-based explanation of the value premium. Journal of Finance, 62, 55-92.

Lioui, A., Maio, P. 2014. Interest rate risk and the cross-section of stock returns. Journal of Financial and Quantitative Analysis, Forthcoming.

Lucca, D., Moench, E. 2014. The pre-FOMC announcement drift. Working paper.

Maio, P. 2014. Another look at the stock return response to monetary policy actions. Review of Finance, 18, 1-51. 
Menzly, L., Santos, T., Veronesi, P. 2004. Understanding predictability. Journal of Political Economy, February, 1-47.

Merton, R. 1973. An intertemporal capital asset pricing model. Econometrica, 41, 867887.

Nagel, S. 2005. Short sales, institutional ownership, and the cross-section of stock returns. Journal of Financial Economics, 78, 277-309.

Novy-Marx, R., Velikov, M. 2014. Anomalies and their cost of trading. Working paper.

Pastor, L., Stambaugh, R. F. 2003. Liquidity risk and expected stock returns. Journal of Political Economy, 111, 642-685.

Patelis, A. 1997. Stock return predictability and the role of monetary policy. Journal of Finance, 52, 1951-1972.

Rigobon, R., Sack, B. 2003. Measuring the reaction of monetary policy to the stock market. Quarterly Journal of Economics, 118, 639-669.

Santos, T., Veronesi, P. 2006. Labor income and predictable stock returns. Review of Financial Studies, 19, 1-44.

Santos, T., Veronesi, P. 2010. Habit formation, the cross-section of stock returns, and the cash-flow risk puzzle. Journal of Financial Economics, 98, 385-413.

Savor, P., Wilson, M. 2013. How much do investors care about macroeconomic risk? Evidence from scheduled economic announcements. Journal of Financial and Quantitative Analysis, 48, 343-375.

Savor, P., Wilson, M. 2014. Asset pricing: A tale of two days. Journal of Financial Economics, 113, 171-201. 
Schwert, G. W. 1981. The adjustment of stock prices to information about inflation. Journal of Finance, 36, 15-29.

Thorbecke, W. 1997. On stock market returns and monetary policy. Journal of Finance, $52,635-654$.

Woodford, M. 2001. Monetary policy in the information economy. Symposium on Economic Policy for the Information Economy. 
Table 1: Market excess returns on FOMC days

The table reports results from time series regressions of daily excess returns to the CRSP value-weighted portfolio (in \%) on a constant and indicator variables for days with Federal Open Market Committee (FOMC) meetings. Specifications (1) - (5) include indicators for days with scheduled Federal Open Market Committee (FOMC) meetings (153 days), scheduled FOMC meetings with surprise hikes (43 days), scheduled FOMC meetings with no surprises (54 days), scheduled FOMC meetings with surprise cuts (56 days), and unscheduled FOMC meetings (24 days), respectively. The last specification includes all indicator variables used in specifications (2) - (5). The 177 FOMC days come from Kenneth Kuttner's website. The signs of the surprises are determined by the measure used in Kuttner (2001). The sample period is June 1989 to June 2008.

\begin{tabular}{|c|c|c|c|c|c|c|}
\hline Const & $\begin{array}{l}(1) \\
0.02 \\
{[1.51]}\end{array}$ & $\begin{array}{l}(2) \\
0.03 \\
{[1.94]}\end{array}$ & $\begin{array}{l}(3) \\
0.03 \\
{[1.91]}\end{array}$ & $\begin{array}{l}(4) \\
0.02 \\
{[1.63]}\end{array}$ & $\begin{array}{l}(5) \\
0.03 \\
{[1.86]}\end{array}$ & $\begin{array}{l}(6) \\
0.02 \\
{[1.38]}\end{array}$ \\
\hline $\mathbb{1}_{\text {FOMC Scheduled Meeting }}$ & $\begin{array}{l}0.20 \\
{[2.51]}\end{array}$ & & & & & \\
\hline $\mathbb{1}_{\text {FOMC Scheduled Meeting, Surprise Hike }}$ & & $\begin{array}{l}0.06 \\
{[0.39]}\end{array}$ & & & & $\begin{array}{l}0.07 \\
{[0.44]}\end{array}$ \\
\hline $\mathbb{1}_{\text {FOMC Scheduled Meeting, No Surprise }}$ & & & $\begin{array}{l}0.08 \\
{[0.61]}\end{array}$ & & & $\begin{array}{l}0.09 \\
{[0.67]}\end{array}$ \\
\hline $\mathbb{1}_{\text {FOMC Scheduled Meeting, Surprise Cut }}$ & & & & $\begin{array}{l}0.42 \\
{[3.17]}\end{array}$ & & $\begin{array}{l}0.42 \\
{[3.19]}\end{array}$ \\
\hline $\mathbb{1}_{\text {FOMC Unscheduled }}$ & & & & & $\begin{array}{l}0.34 \\
{[1.69]}\end{array}$ & $\begin{array}{l}0.35 \\
{[1.73]}\end{array}$ \\
\hline
\end{tabular}


Table 2: CAPM performance on FOMC vs. non-FOMC days

The table reports average daily returns to ten CAPM beta-sorted portfolios for different holding periods. The betas used for sorting are estimated using rolling 12 months of daily returns. Panel A reports full-sample betas, estimated using the realized portfolio returns. Panel B reports average returns and [t-stats] of the portfolios for days with Federal Open Market Committee (FOMC) meetings (177 days), no FOMC meetings (4737 days), scheduled FOMC meetings with surprise hikes (43 days), scheduled FOMC meetings with no surprises (54 days), scheduled FOMC meetings with surprise cuts (56 days), and unscheduled FOMC meetings (24 days). The 177 FOMC days come from Kenneth Kuttner's website. The signs of the surprises follow Kuttner (2001). The sample period is June 1989 to June 2008.

\begin{tabular}{|c|c|c|c|c|c|c|c|c|c|c|c|}
\hline \multicolumn{12}{|c|}{ Panel A: Realized portfolio betas } \\
\hline \multirow[b]{2}{*}{ Betas } & $(\mathrm{L})$ & (2) & (3) & (4) & $(5)$ & (6) & (7) & $(8)$ & (9) & $(\mathrm{H})$ & \multirow[t]{2}{*}{$\begin{array}{l}(\mathrm{H})- \\
(\mathrm{L})\end{array}$} \\
\hline & 0.20 & 0.34 & 0.48 & 0.57 & 0.67 & 0.81 & 0.94 & 1.16 & 1.43 & 1.84 & \\
\hline \multicolumn{12}{|c|}{ Panel B: Average returns for different types of days } \\
\hline All days & $\begin{array}{l}0.02 \\
{[1.63]}\end{array}$ & $\begin{array}{l}0.02 \\
{[2.55]}\end{array}$ & $\begin{array}{l}0.02 \\
{[2.37]}\end{array}$ & $\begin{array}{l}0.02 \\
{[2.07]}\end{array}$ & $\begin{array}{l}0.03 \\
{[2.49]}\end{array}$ & $\begin{array}{l}0.03 \\
{[2.16]}\end{array}$ & $\begin{array}{l}0.03 \\
{[1.82]}\end{array}$ & $\begin{array}{l}0.03 \\
{[1.54]}\end{array}$ & $\begin{array}{l}0.02 \\
{[0.89]}\end{array}$ & $\begin{array}{l}0.02 \\
{[0.78]}\end{array}$ & $\begin{array}{l}0.01 \\
{[0.16]}\end{array}$ \\
\hline FOMC days & $\begin{array}{l}-0.02 \\
{[-0.37]}\end{array}$ & $\begin{array}{l}0.12 \\
{[2.31]}\end{array}$ & $\begin{array}{l}0.09 \\
{[1.55]}\end{array}$ & $\begin{array}{l}0.14 \\
{[2.33]}\end{array}$ & $\begin{array}{l}0.18 \\
{[2.91]}\end{array}$ & $\begin{array}{l}0.19 \\
{[2.57]}\end{array}$ & $\begin{array}{l}0.20 \\
{[2.40]}\end{array}$ & $\begin{array}{l}0.23 \\
{[2.38]}\end{array}$ & $\begin{array}{l}0.27 \\
{[2.28]}\end{array}$ & $\begin{array}{l}0.32 \\
{[1.92]}\end{array}$ & $\begin{array}{l}0.34 \\
{[1.94]}\end{array}$ \\
\hline Non-FOMC days & $\begin{array}{l}0.02 \\
{[1.72]}\end{array}$ & $\begin{array}{l}0.02 \\
{[2.16]}\end{array}$ & $\begin{array}{l}0.02 \\
{[2.13]}\end{array}$ & $\begin{array}{l}0.02 \\
{[1.69]}\end{array}$ & $\begin{array}{l}0.02 \\
{[2.02]}\end{array}$ & $\begin{array}{l}0.02 \\
{[1.72]}\end{array}$ & $\begin{array}{l}0.02 \\
{[1.42]}\end{array}$ & $\begin{array}{l}0.02 \\
{[1.15]}\end{array}$ & $\begin{array}{l}0.01 \\
{[0.51]}\end{array}$ & $\begin{array}{l}0.01 \\
{[0.45]}\end{array}$ & $\begin{array}{l}-0.01 \\
{[-0.19]}\end{array}$ \\
\hline FOMC sched., surprise hike & $\begin{array}{l}-0.14 \\
{[-1.17]}\end{array}$ & $\begin{array}{l}0.09 \\
{[0.88]}\end{array}$ & $\begin{array}{l}-0.10 \\
{[-0.80]}\end{array}$ & $\begin{array}{l}0.07 \\
{[0.46]}\end{array}$ & $\begin{array}{l}0.12 \\
{[0.73]}\end{array}$ & $\begin{array}{l}-0.00 \\
{[-0.01]}\end{array}$ & $\begin{array}{l}0.02 \\
{[0.09]}\end{array}$ & $\begin{array}{l}0.06 \\
{[0.22]}\end{array}$ & $\begin{array}{l}0.06 \\
{[0.18]}\end{array}$ & $\begin{array}{l}-0.03 \\
{[-0.06]}\end{array}$ & $\begin{array}{l}0.11 \\
{[0.24]}\end{array}$ \\
\hline FOMC sched., no surprise & $\begin{array}{l}0.06 \\
{[0.61]}\end{array}$ & $\begin{array}{l}0.05 \\
{[0.48]}\end{array}$ & $\begin{array}{l}0.07 \\
{[0.73]}\end{array}$ & $\begin{array}{l}0.08 \\
{[0.86]}\end{array}$ & $\begin{array}{l}0.13 \\
{[1.48]}\end{array}$ & $\begin{array}{l}0.12 \\
{[1.49]}\end{array}$ & $\begin{array}{l}0.18 \\
{[1.88]}\end{array}$ & $\begin{array}{l}0.11 \\
{[0.88]}\end{array}$ & $\begin{array}{l}0.11 \\
{[0.77]}\end{array}$ & $\begin{array}{l}0.10 \\
{[0.45]}\end{array}$ & $\begin{array}{l}0.04 \\
{[0.17]}\end{array}$ \\
\hline FOMC sched., surprise cut & $\begin{array}{l}-0.01 \\
{[-0.13]}\end{array}$ & $\begin{array}{l}0.22 \\
{[2.66]}\end{array}$ & $\begin{array}{l}0.27 \\
{[2.84]}\end{array}$ & $\begin{array}{l}0.25 \\
{[3.17]}\end{array}$ & $\begin{array}{l}0.29 \\
{[3.32]}\end{array}$ & $\begin{array}{l}0.41 \\
{[3.62]}\end{array}$ & $\begin{array}{l}0.36 \\
{[2.88]}\end{array}$ & $\begin{array}{l}0.48 \\
{[3.62]}\end{array}$ & $\begin{array}{l}0.59 \\
{[3.66]}\end{array}$ & $\begin{array}{l}0.80 \\
{[3.62]}\end{array}$ & $\begin{array}{l}0.81 \\
{[3.46]}\end{array}$ \\
\hline FOMC unsched. & $\begin{array}{l}-0.07 \\
{[-0.24]}\end{array}$ & $\begin{array}{l}-0.07 \\
{[-0.32]}\end{array}$ & $\begin{array}{l}-0.12 \\
{[-0.58]}\end{array}$ & $\begin{array}{l}-0.18 \\
{[-0.77]}\end{array}$ & $\begin{array}{l}0.03 \\
{[0.11]}\end{array}$ & $\begin{array}{l}0.22 \\
{[0.53]}\end{array}$ & $\begin{array}{l}0.31 \\
{[0.56]}\end{array}$ & $\begin{array}{l}0.62 \\
{[0.90]}\end{array}$ & $\begin{array}{l}1.03 \\
{[1.05]}\end{array}$ & $\begin{array}{l}1.43 \\
{[1.34]}\end{array}$ & $\begin{array}{l}1.50 \\
{[1.22]}\end{array}$ \\
\hline
\end{tabular}


Table 3: Daily trading strategy based on surprise FOMC rate cuts

This table reports results for a trading strategy based on stocks' three-day cumulative abnormal returns around Federal Open Market Committee (FOMC) meetings in which there is a surprise rate cut. The surprise cuts are identified following Kuttner (2001). The sample covers 78 surprise cuts between 06/05/1989 and 06/25/2008. At the end of the day after each event, three-day (t-1 to $t+1$ ) cumulative abnormal returns around the event are computed for all stocks. Then, stocks are grouped into five portfolios based on their 3-day CARs using NYSE breakpoints. Stocks are held until the next FOMC meeting with a surprise cut or for 31 trading days, whichever period is shorter. Panel A reports average daily returns to the five portfolios for days in which positions are held, as well as the returns to a portfolio that is long stocks with lowest returns around FOMC cuts and short stocks with highest returns around FOMC cuts. Panel B reports average CAPM $\beta$ 's, daily trading volume, relative bid-ask spread, and Amihud (2002) illiquidity for each portfolio for the 78 days.

\begin{tabular}{|c|c|c|c|c|c|c|}
\hline Portfolio & $(\mathrm{L})$ & (2) & (3) & (4) & $(\mathrm{H})$ & $(\mathrm{L})-(\mathrm{H})$ \\
\hline \multicolumn{7}{|c|}{ Panel A: Average daily excess returns } \\
\hline$r^{e}$ & $\begin{array}{l}4.12 \\
{[1.66]}\end{array}$ & $\begin{array}{l}3.17 \\
{[1.56]}\end{array}$ & $\begin{array}{l}2.08 \\
{[1.07]}\end{array}$ & $\begin{array}{l}1.41 \\
{[0.69]}\end{array}$ & $\begin{array}{l}-0.95 \\
{[-0.38]}\end{array}$ & $\begin{array}{l}5.07 \\
{[3.12]}\end{array}$ \\
\hline \multicolumn{7}{|c|}{ Panel B: Average characteristics } \\
\hline CAPM $\beta$ & 1.14 & 0.98 & 0.92 & 0.96 & 1.10 & \\
\hline Volume $\left(\div 10^{6}\right)$ & 3.96 & 3.53 & 3.64 & 3.98 & 4.94 & \\
\hline Relative bid-ask spread (\%) & 1.62 & 1.20 & 1.35 & 1.16 & 1.43 & \\
\hline Illiquidity $\left(\times 10^{5}\right)$ & 1.25 & 0.86 & 0.54 & 0.46 & 0.84 & \\
\hline
\end{tabular}


Table 4: Descriptive statistics for monthly monetary policy proxies

The table documents descriptive statistics for the monetary policy shocks examined in this study. The series examined are the effective Fed funds rate $\left(r_{F F}\right)$, 1-month London Interbank Offer Rate $\left(r_{L I B O R 1 M}\right)$, the Fed funds futures rate $\left(f_{F F}\right)$, and the 1-month LIBOR futures rate $\left(f_{L I B O R 1 M}\right)$. Panel A reports averages, standard deviations and correlations for monthly changes, while Panel B looks at averages, standard deviations, and correlations for the monthly percent changes in these measures. The sample period is $02 / 1986$ to $12 / 2013$ or whenever the shock series are available in that period.

\begin{tabular}{lllll}
\hline \hline \multicolumn{4}{l}{ Panel A: Descriptive statistics and correlations for monthly changes in shocks } \\
Stat & $\Delta r_{F F}$ & $\Delta r_{L I B O R 1 M}$ & $\Delta f_{F F}$ & $\Delta f_{L I B O R 1 M}$ \\
$\mu$ (b.p.) & -2.39 & -2.36 & -2.71 & -2.95 \\
$\sigma$ (b.p) & 85.48 & 32.40 & 21.08 & 29.68
\end{tabular}

Correlations:

$\Delta r_{F F} \quad 1.00$

$\Delta r_{L I B O R 1 M} \quad 0.30$

1.00

$\triangle f_{F F} \quad 0.34$

0.75

1.00

$\Delta f_{L I B O R} 1 M \quad 0.30$

0.96

0.75

1.00

Panel B: Descriptive statistics and correlations for monthly percent changes in shocks

$\begin{array}{lllll}\text { Stat } & \% \Delta r_{F F} & \% \Delta r_{\text {LIBOR } 1 M} & \% \Delta f_{F F} & \% \Delta f_{\text {LIBOR } 1 M} \\ \mu(\%) & 0.85 & -1.12 & -1.73 & -1.54 \\ \sigma(\%) & 27.72 & 12.99 & 14.00 & 13.54\end{array}$

Correlations:

$\% \Delta r_{F F} \quad 1.00$

$\% \Delta r_{L I B O R 1 M} \quad 0.26 \quad 1.00$

$\begin{array}{llll}\% \Delta f_{F F} & 0.47 & 0.64 & 1.00\end{array}$

$\begin{array}{lllll}\% \Delta f_{L I B O R} M & 0.29 & 0.96 & 0.72 & 1.00\end{array}$ 
Table 5: Monetary policy shocks and the cross section

At the end of each month, firms are split into two groups based on the sign of their beta with respect to monetary policy shocks. The betas are estimated using the previous 60 months of data from the following regression: $R_{t}^{e}=\alpha+\beta_{y^{u}} y_{t}^{u}+\varepsilon_{t}$, where $y^{u}$ stands for any of the monetary policy shocks described in Section 3.1. Value-weighted average excess returns are reported for trading strategies that are long stocks with positive betas and short stocks with negative betas. The first column indicates the proxy used for sorting, the second column provides results for the strategy using all firms in the CRSP/COMPUSTAT merged file with 60 months of returns, the third and fourth columns provide results for financial firms (SIC codes between 6000 and 7000) and nonfinacial firms, respectively. Strategies reported in the fifth column only include the 500 largest nonfinancial firms in each month. The final three columns use value-weighted 2-digit SIC, 3-digit SIC, and Fama and French 49 industry portfolios as the universe of assets used for sorting. T-stats are in brackets. Sample period is 02/1991 to 12/2013 or whenever the shock series are available in that period.

\begin{tabular}{|c|c|c|c|c|c|c|c|}
\hline & \multicolumn{4}{|c|}{ Firms } & \multicolumn{3}{|c|}{ Industries } \\
\hline & All & Fin. & Non-Fin. & $\begin{array}{l}500 \\
\text { Largest }\end{array}$ & SIC2d & SIC3d & FF49 \\
\hline$\beta_{\triangle r^{L I B O R 1 M}}$ & $\begin{array}{l}0.26 \\
{[2.03]}\end{array}$ & $\begin{array}{l}0.01 \\
{[0.09]}\end{array}$ & $\begin{array}{l}0.30 \\
{[2.02]}\end{array}$ & $\begin{array}{l}0.32 \\
{[1.92]}\end{array}$ & $\begin{array}{l}0.43 \\
{[2.12]}\end{array}$ & $\begin{array}{l}0.41 \\
{[2.03]}\end{array}$ & $\begin{array}{l}0.20 \\
{[1.40]}\end{array}$ \\
\hline$\beta_{\% \triangle r}{ }_{L I B O R 1 M}$ & $\begin{array}{l}0.22 \\
{[1.82]}\end{array}$ & $\begin{array}{l}-0.04 \\
{[-0.22]}\end{array}$ & $\begin{array}{l}0.28 \\
{[2.00]}\end{array}$ & $\begin{array}{l}0.28 \\
{[1.85]}\end{array}$ & $\begin{array}{l}0.15 \\
{[0.82]}\end{array}$ & $\begin{array}{l}0.39 \\
{[1.96]}\end{array}$ & $\begin{array}{l}0.14 \\
{[1.01]}\end{array}$ \\
\hline$\beta_{\Delta f_{F F}}$ & $\begin{array}{l}0.35 \\
{[2.06]}\end{array}$ & $\begin{array}{l}-0.23 \\
{[-1.07]}\end{array}$ & $\begin{array}{l}0.37 \\
{[1.98]}\end{array}$ & $\begin{array}{l}0.42 \\
{[2.07]}\end{array}$ & $\begin{array}{l}0.38 \\
{[1.66]}\end{array}$ & $\begin{array}{l}0.41 \\
{[1.00]}\end{array}$ & $\begin{array}{l}0.24 \\
{[0.97]}\end{array}$ \\
\hline$\beta_{\% \Delta f^{F F}}$ & $\begin{array}{l}0.37 \\
{[2.30]}\end{array}$ & $\begin{array}{l}-0.44 \\
{[-2.28]}\end{array}$ & $\begin{array}{l}0.49 \\
{[2.79]}\end{array}$ & $\begin{array}{l}0.55 \\
{[2.93]}\end{array}$ & $\begin{array}{l}0.70 \\
{[2.27]}\end{array}$ & $\begin{array}{l}0.11 \\
{[0.37]}\end{array}$ & $\begin{array}{l}0.21 \\
{[0.95]}\end{array}$ \\
\hline$\beta_{\triangle f^{L I B O R 1 M}}$ & $\begin{array}{l}0.40 \\
{[2.97]}\end{array}$ & $\begin{array}{l}-0.10 \\
{[-0.52]}\end{array}$ & $\begin{array}{l}0.49 \\
{[3.26]}\end{array}$ & $\begin{array}{l}0.55 \\
{[3.37]}\end{array}$ & $\begin{array}{l}0.45 \\
{[2.42]}\end{array}$ & $\begin{array}{l}0.34 \\
{[1.50]}\end{array}$ & $\begin{array}{l}0.29 \\
{[1.74]}\end{array}$ \\
\hline$\beta_{\% \triangle f L I B O R 1 M}$ & $\begin{array}{l}0.35 \\
{[2.74]}\end{array}$ & $\begin{array}{l}-0.04 \\
{[-0.19]}\end{array}$ & $\begin{array}{l}0.40 \\
{[2.87]}\end{array}$ & $\begin{array}{l}0.44 \\
{[2.90]}\end{array}$ & $\begin{array}{l}0.31 \\
{[1.88]}\end{array}$ & $\begin{array}{l}0.28 \\
{[1.32]}\end{array}$ & $\begin{array}{l}0.25 \\
{[1.58]}\end{array}$ \\
\hline
\end{tabular}


Table 6: Alphas and five-factor loadings of $\beta_{\% \Delta r_{\text {LIBORIM }} \text {-sorted portfolios }}$

At the end of each month, all nonfinancial firms in the CRSP/COMPUSTAT merged database with 60 months of returns are

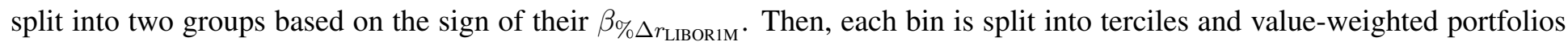
are formed. The $\beta_{\% \triangle r_{L I B O R}}$ 's are estimated using the previous 60 months of data from the following regression: $R_{t}^{e}=$ $\alpha+\beta_{\% \triangle r_{L I B O R}} \% \Delta r_{L I B O R, t}+\varepsilon_{t}$, where $\% \Delta r_{L I B O R}$ is the monthly percent change in the one-month USD LIBOR yield. Panel A reports average excess returns and alphas for the six portfolios and a portfolio that is long stocks in portfolio (H) and short stocks in portfolio (L). The alphas are estimated with respect to the Capital Asset Pricing Model (CAPM), Fama and French (1993) three-factor model (FF3), Carhart (1997) four-factor model (FF4), and the Carhart (1997) model augmented with the Pastor and Stambaugh (2003) liquidity factor (FF4+PS). Panel B documents the loadings on the factors from the five-factor model regressions. T-stats are in brackets. Sample period is 02/1991 to 12/2013.

\begin{tabular}{|c|c|c|c|c|c|c|c|}
\hline \multirow{2}{*}{\multicolumn{2}{|c|}{ Portfolio $\overline{(\mathrm{L})}$}} & & & \multicolumn{3}{|c|}{ Positive $\beta_{\% \Delta r_{\text {LIBORIM }}}$} & \multirow[b]{2}{*}{$(\mathrm{H})-(\mathrm{L})$} \\
\hline & & (2) & (3) & (4) & (5) & $(\mathrm{H})$ & \\
\hline \multicolumn{8}{|c|}{ Panel A: Excess returns and alphas } \\
\hline$r^{e}$ & $\begin{array}{l}0.49 \\
{[1.29]}\end{array}$ & $\begin{array}{l}0.60 \\
{[2.13]}\end{array}$ & $\begin{array}{l}0.52 \\
{[2.13]}\end{array}$ & $\begin{array}{l}0.63 \\
{[2.75]}\end{array}$ & $\begin{array}{l}0.97 \\
{[3.73]}\end{array}$ & $\begin{array}{l}1.29 \\
{[3.23]}\end{array}$ & $\begin{array}{l}0.81 \\
{[2.95]}\end{array}$ \\
\hline$\alpha_{\mathrm{CAPM}}$ & $\begin{array}{l}-0.36 \\
{[-2.31]}\end{array}$ & $\begin{array}{l}-0.05 \\
{[-0.58]}\end{array}$ & $\begin{array}{l}-0.05 \\
{[-0.69]}\end{array}$ & $\begin{array}{l}0.14 \\
{[1.24]}\end{array}$ & $\begin{array}{l}0.43 \\
{[3.13]}\end{array}$ & $\begin{array}{l}0.50 \\
{[2.10]}\end{array}$ & $\begin{array}{l}0.86 \\
{[3.12]}\end{array}$ \\
\hline$\alpha_{\mathrm{FF} 3}$ & $\begin{array}{l}-0.27 \\
{[-1.92]}\end{array}$ & $\begin{array}{l}-0.02 \\
{[-0.19]}\end{array}$ & $\begin{array}{l}-0.04 \\
{[-0.58]}\end{array}$ & $\begin{array}{l}0.13 \\
{[1.20]}\end{array}$ & $\begin{array}{l}0.38 \\
{[2.80]}\end{array}$ & $\begin{array}{l}0.53 \\
{[2.30]}\end{array}$ & $\begin{array}{l}0.80 \\
{[2.88]}\end{array}$ \\
\hline$\alpha_{\mathrm{FF} 4}$ & $\begin{array}{l}-0.20 \\
{[-1.41]}\end{array}$ & $\begin{array}{l}0.02 \\
{[0.23]}\end{array}$ & $\begin{array}{l}-0.02 \\
{[-0.32]}\end{array}$ & $\begin{array}{l}0.13 \\
{[1.21]}\end{array}$ & $\begin{array}{l}0.35 \\
{[2.53]}\end{array}$ & $\begin{array}{l}0.53 \\
{[2.26]}\end{array}$ & $\begin{array}{l}0.73 \\
{[2.58]}\end{array}$ \\
\hline$\alpha_{\mathrm{FF} 4+\mathrm{PS}}$ & $\begin{array}{l}-0.22 \\
{[-1.52]}\end{array}$ & $\begin{array}{l}0.00 \\
{[0.03]}\end{array}$ & $\begin{array}{l}-0.03 \\
{[-0.47]}\end{array}$ & $\begin{array}{l}0.13 \\
{[1.14]}\end{array}$ & $\begin{array}{l}0.34 \\
{[2.46]}\end{array}$ & $\begin{array}{l}0.43 \\
{[1.84]}\end{array}$ & $\begin{array}{l}0.65 \\
{[2.28]}\end{array}$ \\
\hline \multicolumn{8}{|c|}{ Panel B: Loadings on 5-factor model } \\
\hline$\beta_{\mathrm{mkt}}$ & $\begin{array}{l}1.20 \\
{[34.85]}\end{array}$ & $\begin{array}{l}0.98 \\
{[43.47]}\end{array}$ & $\begin{array}{l}0.90 \\
{[50.18]}\end{array}$ & $\begin{array}{l}0.79 \\
{[29.25]}\end{array}$ & $\begin{array}{l}0.90 \\
{[27.20]}\end{array}$ & $\begin{array}{l}1.12 \\
{[20.23]}\end{array}$ & $\begin{array}{l}-0.08 \\
{[-1.11]}\end{array}$ \\
\hline$\beta_{\mathrm{smb}}$ & $\begin{array}{l}0.17 \\
{[3.91]}\end{array}$ & $\begin{array}{l}-0.03 \\
{[-1.13]}\end{array}$ & $\begin{array}{l}-0.10 \\
{[-4.19]}\end{array}$ & $\begin{array}{l}-0.12 \\
{[-3.41]}\end{array}$ & $\begin{array}{l}-0.07 \\
{[-1.65]}\end{array}$ & $\begin{array}{l}0.35 \\
{[4.93]}\end{array}$ & $\begin{array}{l}0.18 \\
{[2.05]}\end{array}$ \\
\hline$\beta_{\mathrm{hml}}$ & $\begin{array}{l}-0.27 \\
{[-5.61]}\end{array}$ & $\begin{array}{l}-0.08 \\
{[-2.61]}\end{array}$ & $\begin{array}{l}0.01 \\
{[0.27]}\end{array}$ & $\begin{array}{l}0.05 \\
{[1.48]}\end{array}$ & $\begin{array}{l}0.15 \\
{[3.28]}\end{array}$ & $\begin{array}{l}-0.14 \\
{[-1.80]}\end{array}$ & $\begin{array}{l}0.13 \\
{[1.37]}\end{array}$ \\
\hline$\beta_{\text {umd }}$ & $\begin{array}{l}-0.08 \\
{[-2.91]}\end{array}$ & $\begin{array}{l}-0.05 \\
{[-2.39]}\end{array}$ & $\begin{array}{l}-0.02 \\
{[-1.50]}\end{array}$ & $\begin{array}{l}-0.00 \\
{[-0.20]}\end{array}$ & $\begin{array}{l}0.04 \\
{[1.31]}\end{array}$ & $\begin{array}{l}0.00 \\
{[0.02]}\end{array}$ & $\begin{array}{l}0.08 \\
{[1.49]}\end{array}$ \\
\hline$\beta_{\text {liq }}$ & $\begin{array}{l}0.03 \\
{[0.92]}\end{array}$ & $\begin{array}{l}0.03 \\
{[1.45]}\end{array}$ & $\begin{array}{l}0.02 \\
{[1.15]}\end{array}$ & $\begin{array}{l}0.01 \\
{[0.42]}\end{array}$ & $\begin{array}{l}0.01 \\
{[0.34]}\end{array}$ & $\begin{array}{l}0.18 \\
{[3.24]}\end{array}$ & $\begin{array}{l}0.15 \\
{[2.19]}\end{array}$ \\
\hline
\end{tabular}


Table 7: Double sorts

The table reports average excess returns and alphas for conditional $\beta_{\% \Delta r_{L I B O R 1 M}}$ strategies, constructed from double-sorts on $\beta_{\% \triangle r_{L I B O R 1 M}}$ and each of the 23 anomaly signals from Novy-Marx and Velikov (2014). In each month, all nonfinancial firms in the CRSP/COMPUSTAT merged database with 60 months of returns are sorted into terciles based on one of the 23 signals. Then, within each tercile, stocks are sorted into deciles based on their $\beta_{\% \triangle r_{L I B O R 1 M}}$. The $\beta_{\% \triangle r_{L I B O R}}$ 's are estimated using the previous 60 months of data from the following regression: $R_{t}^{e}=\alpha+\beta_{\% \Delta r_{L I B O R}} \% \Delta r_{L I B O R, t}+\varepsilon_{t}$, where $\% \Delta r_{L I B O R}$ is the monthly percent change in the one-month USD LIBOR yield. The strategies are long all stocks in the top $\beta_{\% \triangle r_{L I B O R 1 M}}$ deciles and short all stocks in the bottom $\beta_{\% \triangle r_{L I B O R 1 M}}$ deciles, across all terciles. NYSE breakpoints are used for the sorts. Panel A present value-weighted average excess returns, while Panels B, C, and D report CAPM, Fama and French 3-factor model, and Fama and French 4-factor model alphas, respectively. T-stats are in brackets. Sample period is 02/1991 to 12/2013.

\begin{tabular}{|c|c|c|c|c|c|c|c|c|c|c|c|c|c|c|c|c|c|c|c|c|c|c|c|}
\hline $\begin{array}{l}\text { त्रे } \\
\text { 产 } \\
\text { 安 }\end{array}$ & $\stackrel{\sim}{2}$ & 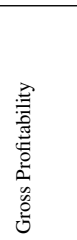 & $\frac{\mathscr{g}}{\frac{\partial}{\nu}}$ & 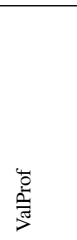 & 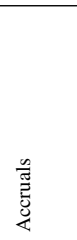 & 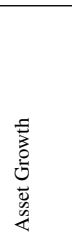 & 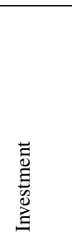 & 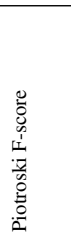 & 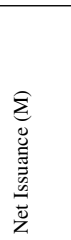 & 㟧 & 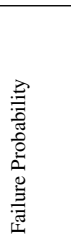 & 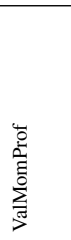 & $\sum_{j}^{E}$ & 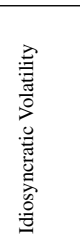 & 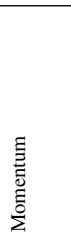 & 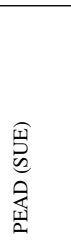 & 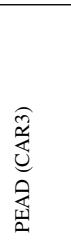 & 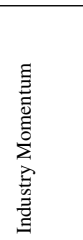 & 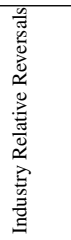 & 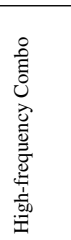 & 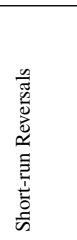 & 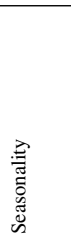 & 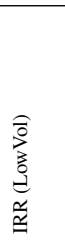 \\
\hline \multicolumn{24}{|c|}{ Panel A: Excess return on the $\beta_{\% \Delta r_{L I B O R 1 M}}$ strategy } \\
\hline$r^{e}$ & $\begin{array}{l}0.51 \\
{[2.05]}\end{array}$ & $\begin{array}{l}0.50 \\
{[2.11]}\end{array}$ & $\begin{array}{l}0.51 \\
{[2.10]}\end{array}$ & $\begin{array}{l}0.56 \\
{[2.20]}\end{array}$ & $\begin{array}{l}0.57 \\
{[2.18]}\end{array}$ & $\begin{array}{l}0.63 \\
{[2.48]}\end{array}$ & $\begin{array}{l}0.50 \\
{[1.99]}\end{array}$ & $\begin{array}{l}0.62 \\
{[2.55]}\end{array}$ & $\begin{array}{l}0.75 \\
{[2.73]}\end{array}$ & $\begin{array}{l}0.60 \\
{[2.16]}\end{array}$ & $\begin{array}{l}0.51 \\
{[1.94]}\end{array}$ & $\begin{array}{l}0.70 \\
{[2.45]}\end{array}$ & $\begin{array}{l}0.57 \\
{[2.13]}\end{array}$ & $\begin{array}{l}0.53 \\
{[2.03]}\end{array}$ & $\begin{array}{l}0.74 \\
{[2.77]}\end{array}$ & $\begin{array}{l}0.83 \\
{[2.96]}\end{array}$ & $\begin{array}{l}0.82 \\
{[2.99]}\end{array}$ & $\begin{array}{l}0.77 \\
{[2.79]}\end{array}$ & $\begin{array}{l}0.64 \\
{[2.34]}\end{array}$ & $\begin{array}{l}0.81 \\
{[2.83]}\end{array}$ & $\begin{array}{l}0.45 \\
{[1.72]}\end{array}$ & $\begin{array}{l}0.64 \\
{[2.27]}\end{array}$ & $\begin{array}{l}0.46 \\
{[1.73]}\end{array}$ \\
\hline \multicolumn{24}{|c|}{ Panel B: CAPM alphas on the $\beta \% \Delta r_{L I B O R 1 M}$ strategy } \\
\hline$\alpha_{C A P M}$ & $\begin{array}{l}0.66 \\
{[2.70]}\end{array}$ & $\begin{array}{l}0.61 \\
{[2.56]}\end{array}$ & $\begin{array}{l}0.64 \\
{[2.69]}\end{array}$ & $\begin{array}{l}0.71 \\
{[2.83]}\end{array}$ & $\begin{array}{l}0.73 \\
{[2.88]}\end{array}$ & $\begin{array}{l}0.76 \\
{[3.03]}\end{array}$ & $\begin{array}{l}0.63 \\
{[2.56]}\end{array}$ & $\begin{array}{l}0.75 \\
{[3.11]}\end{array}$ & $\begin{array}{l}0.89 \\
{[3.25]}\end{array}$ & $\begin{array}{l}0.75 \\
{[2.71]}\end{array}$ & $\begin{array}{l}0.68 \\
{[2.67]}\end{array}$ & $\begin{array}{l}0.91 \\
{[3.33]}\end{array}$ & $\begin{array}{l}0.75 \\
{[2.91]}\end{array}$ & $\begin{array}{l}0.71 \\
{[2.80]}\end{array}$ & $\begin{array}{l}0.95 \\
{[3.71]}\end{array}$ & $\begin{array}{l}0.99 \\
{[3.58]}\end{array}$ & $\begin{array}{l}0.96 \\
{[3.52]}\end{array}$ & $\begin{array}{l}0.94 \\
{[3.53]}\end{array}$ & $\begin{array}{l}0.79 \\
{[2.92]}\end{array}$ & $\begin{array}{l}0.99 \\
{[3.55]}\end{array}$ & $\begin{array}{l}0.56 \\
{[2.17]}\end{array}$ & $\begin{array}{l}0.80 \\
{[2.87]}\end{array}$ & $\begin{array}{l}0.64 \\
{[2.44]}\end{array}$ \\
\hline \multicolumn{24}{|c|}{ Panel C: Fama-French 3-factor model alphas on the $\beta_{\% \Delta r_{L I B O R 1 M}}$ strategy } \\
\hline$\alpha_{F F 3}$ & $\begin{array}{l}0.53 \\
{[2.28]}\end{array}$ & $\begin{array}{l}0.56 \\
{[2.35]}\end{array}$ & $\begin{array}{l}0.59 \\
{[2.53]}\end{array}$ & $\begin{array}{l}0.60 \\
{[2.46]}\end{array}$ & $\begin{array}{l}0.65 \\
{[2.61]}\end{array}$ & $\begin{array}{l}0.71 \\
{[2.87]}\end{array}$ & $\begin{array}{l}0.56 \\
{[2.36]}\end{array}$ & $\begin{array}{l}0.68 \\
{[2.89]}\end{array}$ & $\begin{array}{l}0.81 \\
{[2.94]}\end{array}$ & $\begin{array}{l}0.69 \\
{[2.45]}\end{array}$ & $\begin{array}{l}0.60 \\
{[2.38]}\end{array}$ & $\begin{array}{l}0.81 \\
{[2.95]}\end{array}$ & $\begin{array}{l}0.73 \\
{[2.79]}\end{array}$ & $\begin{array}{l}0.63 \\
{[2.51]}\end{array}$ & $\begin{array}{l}0.90 \\
{[3.53]}\end{array}$ & $\begin{array}{l}0.91 \\
{[3.29]}\end{array}$ & $\begin{array}{l}0.90 \\
{[3.26]}\end{array}$ & $\begin{array}{l}0.89 \\
{[3.32]}\end{array}$ & $\begin{array}{l}0.72 \\
{[2.65]}\end{array}$ & $\begin{array}{l}0.89 \\
{[3.19]}\end{array}$ & $\begin{array}{l}0.51 \\
{[1.98]}\end{array}$ & $\begin{array}{l}0.73 \\
{[2.60]}\end{array}$ & $\begin{array}{l}0.59 \\
{[2.25]}\end{array}$ \\
\hline \multicolumn{24}{|c|}{ Panel D: Fama-French 4-factor model alphas on the $\beta_{\%} \Delta r_{L I B O R 1 M}$ strategy } \\
\hline$\alpha_{F F 4}$ & $\begin{array}{l}0.40 \\
{[1.73]}\end{array}$ & $\begin{array}{l}0.42 \\
{[1.77]}\end{array}$ & $\begin{array}{l}0.48 \\
{[2.03]}\end{array}$ & $\begin{array}{l}0.43 \\
{[1.78]}\end{array}$ & $\begin{array}{l}0.49 \\
{[1.97]}\end{array}$ & $\begin{array}{l}0.56 \\
{[2.29]}\end{array}$ & $\begin{array}{l}0.44 \\
{[1.85]}\end{array}$ & $\begin{array}{l}0.56 \\
{[2.35]}\end{array}$ & $\begin{array}{l}0.79 \\
{[2.81]}\end{array}$ & $\begin{array}{l}0.58 \\
{[2.07]}\end{array}$ & $\begin{array}{l}0.50 \\
{[1.96]}\end{array}$ & $\begin{array}{l}0.78 \\
{[2.79]}\end{array}$ & $\begin{array}{l}0.59 \\
{[2.25]}\end{array}$ & $\begin{array}{l}0.49 \\
{[1.96]}\end{array}$ & $\begin{array}{l}0.78 \\
{[3.05]}\end{array}$ & $\begin{array}{l}0.86 \\
{[3.06]}\end{array}$ & $\begin{array}{l}0.81 \\
{[2.91]}\end{array}$ & $\begin{array}{l}0.87 \\
{[3.19]}\end{array}$ & $\begin{array}{l}0.64 \\
{[2.35]}\end{array}$ & $\begin{array}{l}0.87 \\
{[3.08]}\end{array}$ & $\begin{array}{l}0.45 \\
{[1.71]}\end{array}$ & $\begin{array}{l}0.73 \\
{[2.55]}\end{array}$ & $\begin{array}{l}0.53 \\
{[1.98]}\end{array}$ \\
\hline
\end{tabular}


Table 8: Spanning tests

The table reports average excess returns and spanning tests for the strategy examined in Table 6 and the 23 anomalies from Novy-Marx and Velikov (2014). Panel A reports value-weighted average excess returns on the 23 anomalies, Panel B reports spanning tests of the form $R_{t, i}=\alpha+\beta R_{t, \beta \% \triangle r_{L I B O R 1 M}}+\varepsilon_{t}$, and Panel C reports spanning tests of the form $R_{t, \beta_{\%} \Delta r_{L I B O R 1 M}}=$ $\alpha+\beta R_{t, i}+\varepsilon_{t}$, where $R_{t, i}$ is one of the 23 anomalies, and $R_{t, \beta \% \triangle r_{L I B O R 1 M}}$ is the return on the strategy from Table 6. T-stats are in brackets. Sample period is $02 / 1991$ to $12 / 2013$.

\begin{tabular}{|c|c|c|c|c|c|c|c|c|c|c|c|c|c|c|c|c|c|c|c|c|c|c|c|}
\hline 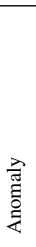 & 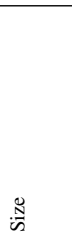 & 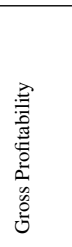 & 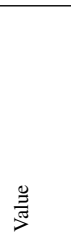 & 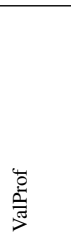 & 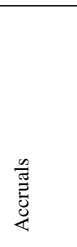 & 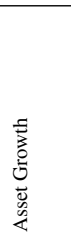 & 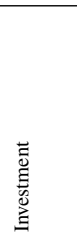 & 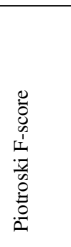 & 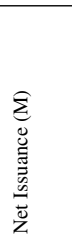 & 嵌 & 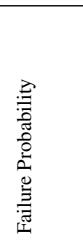 & 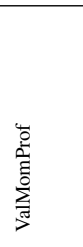 & 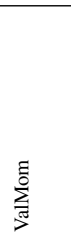 & 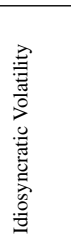 & 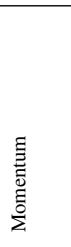 & 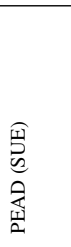 & 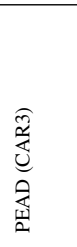 & 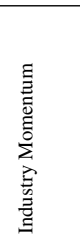 & 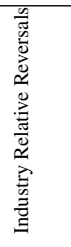 & 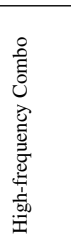 & 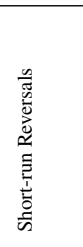 & 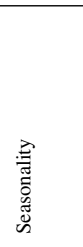 & 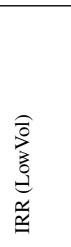 \\
\hline \multicolumn{24}{|c|}{ Panel A: Excess returns on 23 anomalies from Novy-Marx and Velikov (2014) } \\
\hline$r^{e}$ & $\begin{array}{l}0.41 \\
{[1.38]}\end{array}$ & $\begin{array}{l}0.34 \\
{[1.66]}\end{array}$ & $\begin{array}{l}0.32 \\
{[1.25]}\end{array}$ & $\begin{array}{l}0.69 \\
{[2.79]}\end{array}$ & $\begin{array}{l}0.16 \\
{[0.85]}\end{array}$ & $\begin{array}{l}0.36 \\
{[1.47]}\end{array}$ & $\begin{array}{l}0.45 \\
{[2.25]}\end{array}$ & $\begin{array}{l}0.06 \\
{[0.19]}\end{array}$ & $\begin{array}{l}0.53 \\
{[2.22]}\end{array}$ & $\begin{array}{l}0.64 \\
{[1.84]}\end{array}$ & $\begin{array}{l}0.89 \\
{[1.81]}\end{array}$ & $\begin{array}{l}1.19 \\
{[3.53]}\end{array}$ & $\begin{array}{l}0.61 \\
{[1.89]}\end{array}$ & $\begin{array}{l}0.43 \\
{[0.83]}\end{array}$ & $\begin{array}{l}0.93 \\
{[1.86]}\end{array}$ & $\begin{array}{l}0.53 \\
{[2.61]}\end{array}$ & $\begin{array}{l}0.76 \\
{[3.69]}\end{array}$ & $\begin{array}{l}0.36 \\
{[0.88]}\end{array}$ & $\begin{array}{l}0.41 \\
{[1.38]}\end{array}$ & $\begin{array}{l}0.61 \\
{[2.52]}\end{array}$ & $\begin{array}{l}0.10 \\
{[0.26]}\end{array}$ & $\begin{array}{l}0.63 \\
{[2.53]}\end{array}$ & $\begin{array}{l}0.56 \\
{[2.62]}\end{array}$ \\
\hline \multicolumn{24}{|c|}{ Panel B: Spanning tests of the form $R_{t, i}=\alpha+\beta R_{t, \beta_{\% \Delta r}}{ }+\varepsilon_{t}$} \\
\hline$\alpha$ & $\begin{array}{l}0.26 \\
{[0.86]}\end{array}$ & $\begin{array}{l}0.32 \\
{[1.54]}\end{array}$ & $\begin{array}{l}0.29 \\
{[1.08]}\end{array}$ & $\begin{array}{l}0.59 \\
{[2.39]}\end{array}$ & $\begin{array}{l}0.16 \\
{[0.81]}\end{array}$ & $\begin{array}{l}0.38 \\
{[1.52]}\end{array}$ & $\begin{array}{l}0.46 \\
{[2.28]}\end{array}$ & $\begin{array}{l}1 \\
0.02 \\
{[0.05]}\end{array}$ & $\begin{array}{l}0.54 \\
{[2.21]}\end{array}$ & $\begin{array}{l}0.73 \\
{[2.06]}\end{array}$ & $\begin{array}{l}0.83 \\
{[1.65]}\end{array}$ & $\begin{array}{l}0.98 \\
{[2.92]}\end{array}$ & $\begin{array}{l}0.47 \\
{[1.47]}\end{array}$ & $\begin{array}{l}0.52 \\
{[0.98]}\end{array}$ & $\begin{array}{l}0.74 \\
{[1.48]}\end{array}$ & $\begin{array}{l}0.55 \\
{[2.65]}\end{array}$ & $\begin{array}{l}0.80 \\
{[3.87]}\end{array}$ & $\begin{array}{l}0.25 \\
{[0.60]}\end{array}$ & $\begin{array}{l}0.51 \\
{[1.67]}\end{array}$ & $\begin{array}{l}0.53 \\
{[2.15]}\end{array}$ & $\begin{array}{l}0.21 \\
{[0.55]}\end{array}$ & $\begin{array}{l}0.72 \\
{[2.92]}\end{array}$ & $\begin{array}{l}0.54 \\
{[2.46]}\end{array}$ \\
\hline \multirow[t]{2}{*}{$\beta$} & 0.19 & 0.02 & 0.05 & 0.12 & 0.00 & - & & 0.06 & - & & 0.08 & 0.26 & 0.16 & - & 0.23 & & & 0.14 & & 0.10 & & & 0.03 \\
\hline & [2.93] & [0.53] & [0.85] & [2.14] & [0.11] & $\begin{array}{l}0.02 \\
{[-} \\
0.39]\end{array}$ & $\begin{array}{l}0.02 \\
{[-} \\
0.38]\end{array}$ & [0.80] & $\begin{array}{l}0.01 \\
{[-} \\
0.16]\end{array}$ & $\begin{array}{l}0.11 \\
{[-} \\
1.41]\end{array}$ & {$[0.74]$} & [3.57] & [2.34] & $\begin{array}{l}0.10 \\
{[-} \\
0.88]\end{array}$ & [2.08] & $\begin{array}{l}0.02 \\
{[-} \\
0.47]\end{array}$ & $\begin{array}{l}0.06 \\
{[-} \\
1.30]\end{array}$ & & $\begin{array}{l}0.11 \\
{[-} \\
1.73]\end{array}$ & [1.94] & $\begin{array}{l}0.14 \\
{[-} \\
1.66]\end{array}$ & $\begin{array}{l}0.12 \\
{[-} \\
2.28]\end{array}$ & {$[0.66]$} \\
\hline \multicolumn{24}{|c|}{ Panel C: Spanning tests of the form $R_{t, \beta_{\%} \Delta r} r_{t B O B 1 M}=\alpha+\beta R_{t, i}+\varepsilon_{t}$} \\
\hline$\alpha$ & $\begin{array}{l}0.74 \\
{[2.74]}\end{array}$ & $\begin{array}{l}0.79 \\
{[2.88]}\end{array}$ & $\begin{array}{l}0.79 \\
{[2.88]}\end{array}$ & $\begin{array}{l}0.71 \\
{[2.58]}\end{array}$ & $\begin{array}{c}\Delta r_{L I B C} \\
0.81 \\
{[2.94]}\end{array}$ & $\begin{array}{c}R 1 M \\
0.82 \\
{[2.97]}\end{array}$ & $\begin{array}{l}0.82 \\
{[2.97]}\end{array}$ & $\begin{array}{l}0.81 \\
{[2.94]}\end{array}$ & $\begin{array}{l}0.81 \\
{[2.94]}\end{array}$ & $\begin{array}{l}0.85 \\
{[3.10]}\end{array}$ & $\begin{array}{l}0.79 \\
{[2.85]}\end{array}$ & $\begin{array}{l}0.60 \\
{[2.20]}\end{array}$ & $\begin{array}{l}0.74 \\
{[2.69]}\end{array}$ & $\begin{array}{l}0.82 \\
{[2.99]}\end{array}$ & $\begin{array}{l}0.74 \\
{[2.72]}\end{array}$ & $\begin{array}{l}0.83 \\
{[2.99]}\end{array}$ & $\begin{array}{l}0.89 \\
{[3.17]}\end{array}$ & $\begin{array}{l}0.79 \\
{[2.88]}\end{array}$ & $\begin{array}{l}0.85 \\
{[3.10]}\end{array}$ & $\begin{array}{l}0.73 \\
{[2.64]}\end{array}$ & $\begin{array}{l}0.82 \\
{[2.99]}\end{array}$ & $\begin{array}{l}0.90 \\
{[3.29]}\end{array}$ & $\begin{array}{l}0.78 \\
{[2.81]}\end{array}$ \\
\hline \multirow[t]{2}{*}{$\beta$} & 0.16 & 0.04 & 0.05 & 0.14 & 0.01 & - & - & 0.04 & - & & 0.02 & 0.17 & 0.12 & & 0.07 & & & 0.06 & & 0.13 & & & 0.05 \\
\hline & [2.93] & [0.53] & [0.85] & [2.14] & [0.11] & $\begin{array}{l}0.03 \\
{[-} \\
0.39]\end{array}$ & $\begin{array}{l}0.03 \\
{[--} \\
0.38]\end{array}$ & [0.80] & $\begin{array}{l}0.01 \\
{[-} \\
0.16]\end{array}$ & $\begin{array}{l}0.07 \\
{[-} \\
1.41]\end{array}$ & {$[0.74]$} & [3.57] & [2.34] & $\begin{array}{l}0.03 \\
{[-} \\
0.88]\end{array}$ & [2.08] & $\begin{array}{l}0.04 \\
{[-} \\
0.47]\end{array}$ & $\begin{array}{l}0.10 \\
{[-} \\
1.30]\end{array}$ & [1.52] & $\begin{array}{l}0.10 \\
{[-} \\
1.73]\end{array}$ & [1.94] & $\begin{array}{l}0.07 \\
{[-} \\
1.66]\end{array}$ & $\begin{array}{l}0.15 \\
{[-} \\
2.28]\end{array}$ & [0.66] \\
\hline
\end{tabular}


Table 9: Fama-MacBeth regressions

The table documents results from Fama-MacBeth regressions of the form $r_{t j}=\beta^{\prime} \mathbf{x}_{t-1, j}+\varepsilon_{t j}$. The characteristics $x_{t-1, j}$ include $\beta_{\% \triangle r_{L I B O R}}$, the $\log$ of market capitalization $(\log (\mathrm{ME}))$, the $\log$ of the book-to-market ratio $(\log (\mathrm{BM}))$, gross profitability (GP/A), standardized unexpected earnings (SUE), asset growth, and momentum $\left(r_{12,1}\right)$. In each month, for each firm, the $\beta_{\% \triangle r_{L I B O R}}$ 's are estimated using the previous 60 months of data from the following regression: $R_{t}^{e}=\alpha+$ $\beta_{\% \Delta r_{L I B O R}} \% \Delta r_{L I B O R, t}+\varepsilon_{t}$, where $\% \Delta r_{L I B O R}$ is the monthly percent change in the one-month USD LIBOR yield. The sample includes all firms in CRSP with at least 5 years of monthly returns. T-stats are in brackets. Sample period is 02/1991 to $12 / 2013$.

\begin{tabular}{|c|c|c|c|c|c|c|c|c|}
\hline \multicolumn{9}{|c|}{ Regressions of the form $r_{t j}=\beta^{\prime} \mathbf{x}_{t j}+\varepsilon_{t j}$} \\
\hline Coefficient & (1) & (2) & (3) & $(4)$ & $(5)$ & (6) & (7) & (8) \\
\hline \multirow{2}{*}{$\beta_{\% \Delta r_{L I B O R}}$} & 0.80 & 0.66 & 0.69 & 0.77 & 0.82 & 0.78 & 0.64 & 0.44 \\
\hline & {$[3.75]$} & [3.27] & [3.35] & {$[3.65]$} & [3.79] & [3.64] & {$[3.53]$} & [2.66] \\
\hline $\log (\mathrm{ME})$ & & $\begin{array}{l}-0.18 \\
{[-3.06]}\end{array}$ & & & & & & $\begin{array}{l}-0.16 \\
{[-2.64]}\end{array}$ \\
\hline \multirow[t]{2}{*}{$\log (\mathrm{BM})$} & & & 0.33 & & & & & 0.17 \\
\hline & & & [3.96] & & & & & {$[1.71]$} \\
\hline \multirow[t]{2}{*}{ GP/A } & & & & 0.59 & & & & 0.52 \\
\hline & & & & [2.96] & & & & [2.65] \\
\hline \multirow[t]{2}{*}{ SUE } & & & & & 0.19 & & & 0.18 \\
\hline & & & & & [8.62] & & & [11.87] \\
\hline \multirow{2}{*}{\multicolumn{2}{|c|}{ Asset Growth }} & & & & & -1.01 & & -0.78 \\
\hline & & & & & & {$[-6.35]$} & & {$[-6.56]$} \\
\hline \multirow[t]{2}{*}{$r_{12,1}$} & & & & & & & 0.12 & 0.06 \\
\hline & & & & & & & {$[0.41]$} & {$[0.24]$} \\
\hline
\end{tabular}


Table 10: Robustness

In each month, all nonfinancial firms in the CRSP/COMPUSTAT merged database are sorted into portfolios based on their beta with respect to changes in monetary policy. The betas are estimated using historical information from the following regression: $R_{t}^{e}=\alpha+\beta_{y^{u}} y_{t}^{u}+\varepsilon_{t}$, where $y^{u}$ stands for the monetary policy shocks described in Section 3.1. The second and fourth columns use a quintile sort, while the third and fifth columns use decile sorts. The last two columns employ New York Stock Exchange (NYSE) breakpoints. Then, a long-short strategy is formed and its valueweighted average excess returns are reported. Panel A estimates the betas using rolling 60 months of data, whereas Panel B uses different estimation horizons, as indicated in the first column. T-stats are in brackets. Sample period is 02/1991 to 12/2013 or whenever the shock series are available in that period.

\begin{tabular}{|c|c|c|c|c|}
\hline & Quintile & Decile & $\begin{array}{l}\text { Quintile } \\
\text { NYSE }\end{array}$ & $\begin{array}{l}\text { Decile } \\
\text { NYSE }\end{array}$ \\
\hline \multicolumn{5}{|c|}{ Panel A: Robustness to other measures } \\
\hline$\beta_{\Delta r L I B O R 1 M}$ & $\begin{array}{l}0.75 \\
{[2.81]}\end{array}$ & $\begin{array}{l}0.95 \\
{[2.51]}\end{array}$ & $\begin{array}{l}0.56 \\
{[2.50]}\end{array}$ & $\begin{array}{l}0.77 \\
{[2.71]}\end{array}$ \\
\hline$\beta_{\% \Delta r^{L I B O R 1 M}}$ & $\begin{array}{l}0.59 \\
{[2.20]}\end{array}$ & $\begin{array}{l}1.01 \\
{[2.83]}\end{array}$ & $\begin{array}{l}0.42 \\
{[1.83]}\end{array}$ & $\begin{array}{l}0.73 \\
{[2.56]}\end{array}$ \\
\hline$\beta_{\Delta f^{F F}}$ & $\begin{array}{l}0.43 \\
{[1.31]}\end{array}$ & $\begin{array}{l}0.65 \\
{[1.66]}\end{array}$ & $\begin{array}{l}0.49 \\
{[1.74]}\end{array}$ & $\begin{array}{l}0.64 \\
{[1.89]}\end{array}$ \\
\hline$\beta_{\% \Delta f F F}$ & $\begin{array}{l}0.51 \\
{[1.54]}\end{array}$ & $\begin{array}{l}0.87 \\
{[2.18]}\end{array}$ & $\begin{array}{l}0.69 \\
{[2.45]}\end{array}$ & $\begin{array}{l}0.55 \\
{[1.59]}\end{array}$ \\
\hline$\beta_{\triangle f^{L I B O R 1 M}}$ & $\begin{array}{l}0.91 \\
{[3.01]}\end{array}$ & $\begin{array}{l}1.28 \\
{[3.11]}\end{array}$ & $\begin{array}{l}0.71 \\
{[2.82]}\end{array}$ & $\begin{array}{l}0.94 \\
{[2.99]}\end{array}$ \\
\hline$\beta_{\% \Delta f L I B O R 1 M}$ & $\begin{array}{l}0.72 \\
{[2.40]}\end{array}$ & $\begin{array}{l}1.35 \\
{[3.52]}\end{array}$ & $\begin{array}{l}0.53 \\
{[2.15]}\end{array}$ & $\begin{array}{l}0.78 \\
{[2.48]}\end{array}$ \\
\hline \multicolumn{5}{|c|}{ Panel B: Robustness to different beta estimation periods using $\beta_{\% \triangle r L I B O R 1 M}$} \\
\hline 2 years & $\begin{array}{l}0.47 \\
{[1.51]}\end{array}$ & $\begin{array}{l}0.56 \\
{[1.45]}\end{array}$ & $\begin{array}{l}0.45 \\
{[1.90]}\end{array}$ & $\begin{array}{l}0.54 \\
{[1.88]}\end{array}$ \\
\hline 3 years & $\begin{array}{l}0.38 \\
{[1.38]}\end{array}$ & $\begin{array}{l}0.95 \\
{[2.72]}\end{array}$ & $\begin{array}{l}0.38 \\
{[1.73]}\end{array}$ & $\begin{array}{l}0.46 \\
{[1.61]}\end{array}$ \\
\hline 10 years & $\begin{array}{l}0.51 \\
{[1.87]}\end{array}$ & $\begin{array}{l}0.60 \\
{[1.65]}\end{array}$ & $\begin{array}{l}0.60 \\
{[2.34]}\end{array}$ & $\begin{array}{l}0.56 \\
{[1.79]}\end{array}$ \\
\hline
\end{tabular}




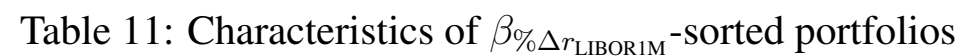

The table reports characteristics for the six portfolios from Table 6. In each month, all nonfinancial firms in the CRSP/COMPUSTAT merged database with 60 months of returns are split into two groups based on the sign of their $\beta_{\%} \Delta r_{\text {LIBORIM }}$. Then, each bin is split into terciles. The $\beta_{\% \triangle r_{L I B O R}}$ 's are estimated using the previous 60 months of data from the following regression: $R_{t}^{e}=\alpha+\beta_{\% \Delta r_{L I B O R}} \% \Delta r_{L I B O R, t}+\varepsilon_{t}$, where $\% \Delta r_{L I B O R}$ is the monthly percent change in the one-month USD

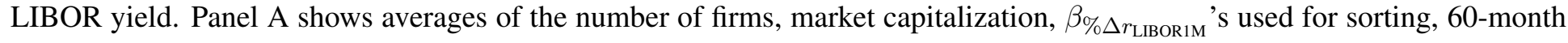
lags and leads of the sorting betas, and the $\beta_{\% \Delta r_{\text {LIBORIM }}}$ of the realized portfolio returns. In Panel $\mathrm{B}$, average book-to-market as well as net income, leverage, operating leverage, and investment as a percent of total assets are reported. Panel $\mathrm{C}$ reports average residual percentage of institional holdings, measured as in Nagel (2005), average idiosyncratic volatility, measured as in Ang et al. (2006) and average illiquidity, measured as in Amihud (2002). Sample period is 02/1991 to 12/2013.

\begin{tabular}{lllllll}
\hline Portfolio & $(\mathrm{L})$ & $(2)$ & $(3)$ & $(4)$ & $(5)$ & $(\mathrm{H})$ \\
Panel A: Portfolio characteristics & & & & & & 361 \\
Number of Firms & 594 & 597 & 597 & 363 & 363 & 1.14 \\
Market Cap $\left(\times 10^{9}\right)$ & 1.33 & 3.43 & 4.39 & 4.65 & 2.52 & 0.45 \\
Sorting $\beta_{\% \Delta r_{L I B O R 1 M}}$ & -0.54 & -0.20 & -0.06 & 0.04 & 0.15 & -0.08 \\
60-month lagged sorting $\beta_{\% \Delta r_{L I B O R 1 M}}$ & -0.09 & -0.08 & -0.08 & -0.08 & -0.08 & -0.08 \\
60-month lead sorting $\beta_{\% \Delta r_{L I B O R 1 M}}$ & -0.10 & -0.07 & -0.05 & -0.05 & -0.06 & -0.11 \\
Realized portfolio $\beta_{\% \Delta r_{L I B O R 1 M}}$ & -0.05 & -0.03 & -0.03 & -0.03 & -0.05 & 82.49 \\
\hline Panel B: Accounting characteristics & & & & & & -6.78 \\
B/M & 65.63 & 65.15 & 72.62 & 70.95 & 74.13 & 22.66 \\
Net Income & -9.99 & -0.86 & 0.99 & 0.51 & -0.67 & 122.49 \\
Leverage & 23.02 & 22.68 & 22.74 & 22.16 & 22.52 & 5.82 \\
Operating Leverage & 118.01 & 113.84 & 115.34 & 114.56 & 118.34 \\
Investment & 4.60 & 3.98 & 4.09 & 5.17 & 5.15 & 38.17 \\
\hline Panel C: Other characteristics & & & & & & 0.04 \\
Residual Inst. Ownership $(\%)$ & 33.46 & 39.70 & 36.55 & 36.46 & 43.70 & 0.50 \\
Idiosyncratic volatility & 0.04 & 0.03 & 0.02 & 0.02 & 0.03 & 0.46 \\
Amihud illiquidity $\left(\times 10^{5}\right)$ & 0.26 & 0.27 & 0.32 & 0.38 & & \\
\hline \hline
\end{tabular}


Table 12: The link to Fed announcements

In each month, all nonfinancial firms in the CRSP/COMPUSTAT merged database with 60

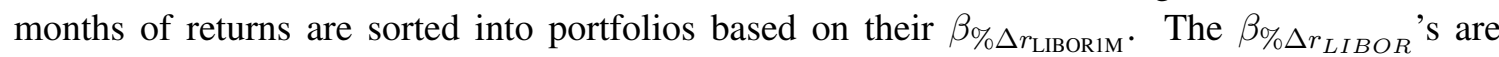
estimated using the previous 60 months of data from the following regression: $R_{t}^{e}=\alpha+$ $\beta_{\% \Delta r_{L I B O R}} \% \Delta r_{L I B O R, t}+\varepsilon_{t}$, where $\% \Delta r_{L I B O R}$ is the monthly percent change in the one-month USD LIBOR yield. The second and fourth columns use a quintile sort, while the third and fifth columns use decile sorts. The last two columns employ New York Stock Exchange (NYSE) breakpoints. Then, a strategy that is long stocks in the high $\beta_{\% \Delta r_{\text {LIBORIM }}}$ portfolio and short stocks in the low $\beta_{\% \Delta r_{\text {LIBOR IM }}}$ portfolio is formed and its value-weighted average excess returns are reported. Panel A uses monthly returns cumulated from CRSP daily data. In Panel B, the analysis in Panel A is repeated, but days on which there are Federal Open Market Committee meetings (FOMC) are excluded. That is, the returns for all stocks and the percent change in LIBOR in the 3 days surrounding the announcements ( $t-1$ to $t+1)$ are set to zero. The 177 FOMC days come from Kenneth Kuttner's website. In Panels C, D, and E, only announcements with surprise hikes, no surprise changes, or surprise cuts to the Fed funds target rate, respectively, are excluded. The signs of the surprises are determined by the measure used in Kuttner (2001). T-stats are in brackets. Sample period is $02 / 1991$ to $06 / 2008$.

\begin{tabular}{|c|c|c|c|c|}
\hline & Quintile & Decile & $\begin{array}{l}\text { Quintile } \\
\text { NYSE }\end{array}$ & $\begin{array}{l}\text { Decile } \\
\text { NYSE }\end{array}$ \\
\hline \multicolumn{5}{|c|}{ Panel A: Monthly returns from daily data } \\
\hline$r_{\beta_{\% \Delta r_{\text {LIBOR IM }}}^{e}}$ & $\begin{array}{l}0.65 \\
{[2.12]}\end{array}$ & $\begin{array}{l}0.93 \\
{[2.05]}\end{array}$ & $\begin{array}{l}0.42 \\
{[1.79]}\end{array}$ & $\begin{array}{l}0.77 \\
{[2.41]}\end{array}$ \\
\hline
\end{tabular}

Panel B: Excluding the 3 days around all announcements (177 events)

\begin{tabular}{|c|c|c|c|}
\hline$r_{\beta_{\% \Delta r_{\text {LIBOR IM }}}^{e}}^{e}$ & $\begin{array}{l}0.12 \\
{[0.44]}\end{array}$ & $\begin{array}{l}0.05 \\
{[0.12]}\end{array}$ & $\begin{array}{l}0.21 \\
{[1.03]}\end{array}$ \\
\hline
\end{tabular}

Panel C: Excluding the 3 days around surprise hikes (45 events)

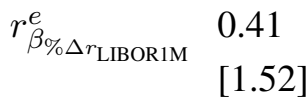
0.76
0.35
0.61
[1.78]
[1.51]

Panel D: Excluding the 3 days around FOMC meetings with no surprise changes (54 events)
$r_{\beta_{\% \Delta r_{\text {LIBOR IM }}}^{e}}^{e} 0.54$
0.66
0.42
0.68
[1.82]
[1.49]
[1.82]
[2.17]

Panel E: Excluding the 3 days around surprise cuts (78 events)

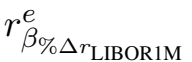
0.05
0.18
0.29
0.27
[0.16]
[0.40]
[1.32]
[0.90] 


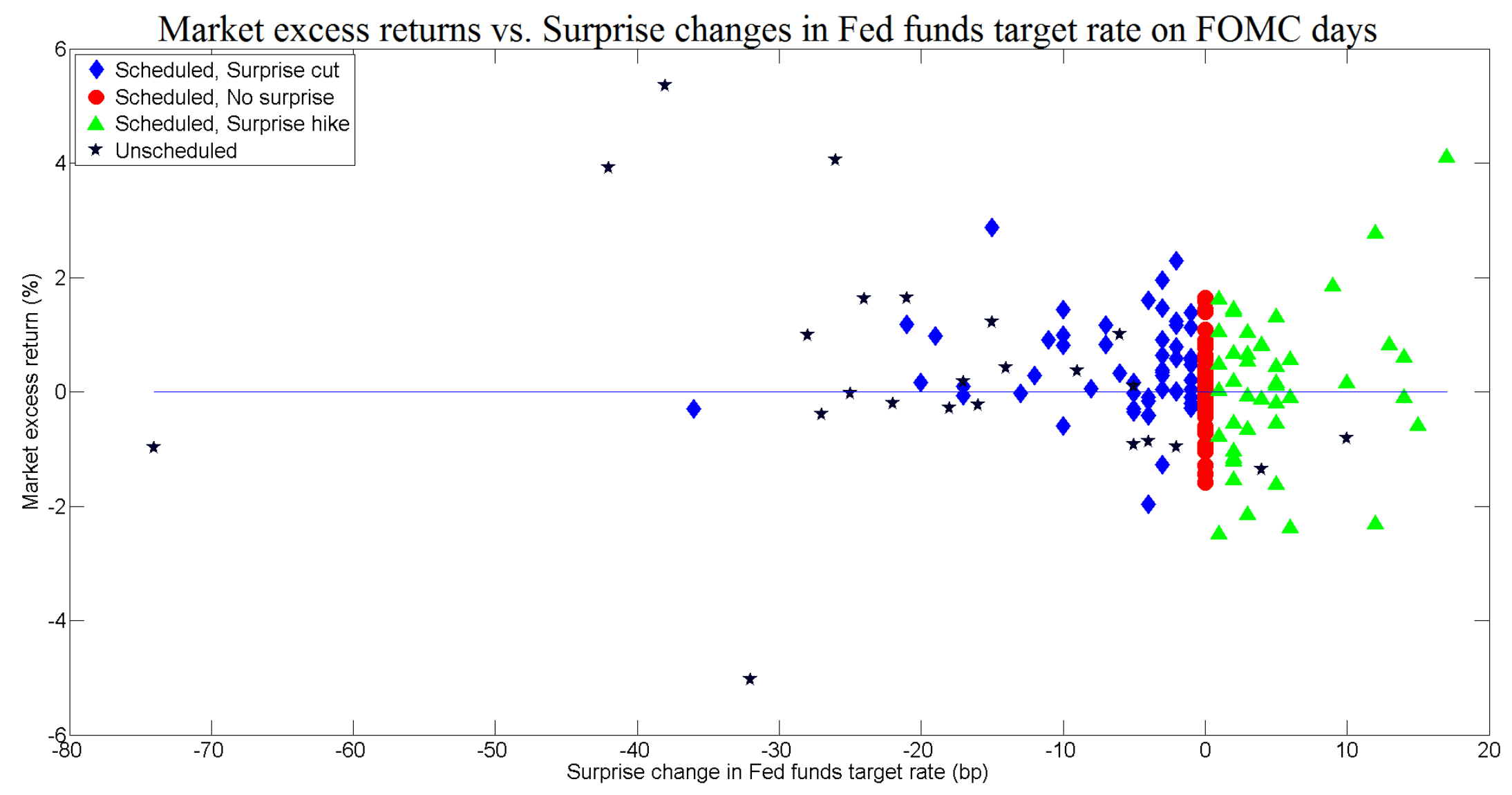

Figure 1: Market excess returns on FOMC days

This figure plots daily excess returns to the CRSP value-weighted portfolio in percent (\%) against surprise changes to the Fed funds target rate in basis points (bp) for days with Federal Open Market Committee (FOMC) meetings. The FOMC meeting days are split into scheduled meetings with surprise rate cuts (56 days), scheduled meetings with no surprises (54 days), scheduled meetings with surprise rate hikes (43 days), and unscheduled meetings ( 24 days). The surprises are identified following Kuttner (2001). The sample covers the 1989-2008 period. 


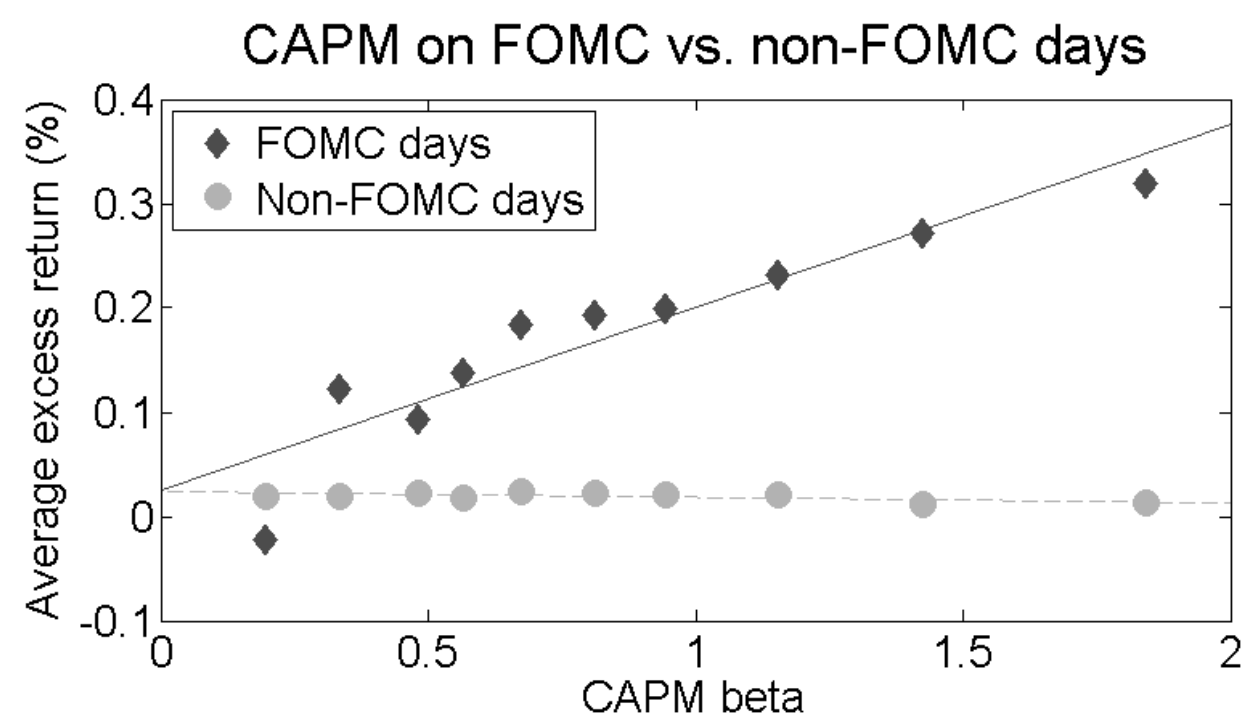

\section{CAPM on FOMC days by type of surprise}

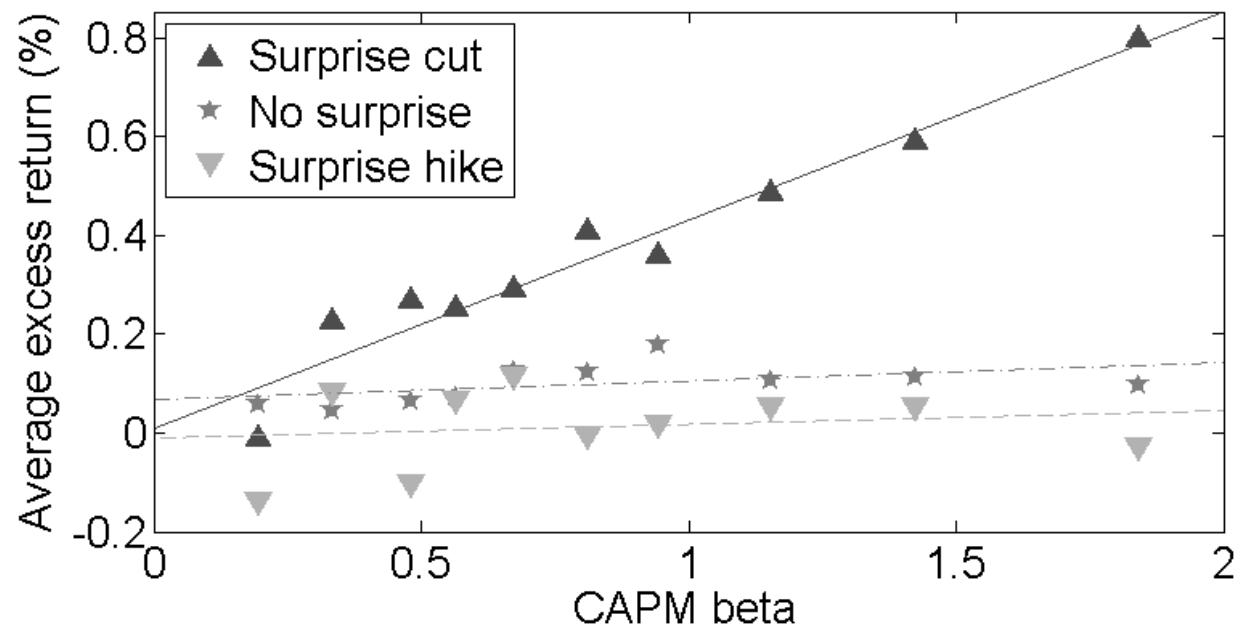

Figure 2: CAPM performance on FOMC days vs. non-FOMC days

The figures plot average daily excess returns in percent (\%) against market betas for ten betasorted portfolios of all NYSE, AMEX, and Nasdaq firms. The figures also include ordinary least squares estimates of the security market line. The top figure separates observations into days with scheduled Federal Open Market Committee (FOMC) meetings (FOMC days) and all other days (Non-FOMC days), following Savor and Wilson (2014). The bottom figure splits FOMC days into days with surprise cuts (56 days), no surprises (54 days), and surprise hikes (43 days). The surprises are identified following Kuttner (2001). The sample covers the 1989-2008 period. For each test portfolio, I use the same estimate of the full-sample beta for all subsamples. 


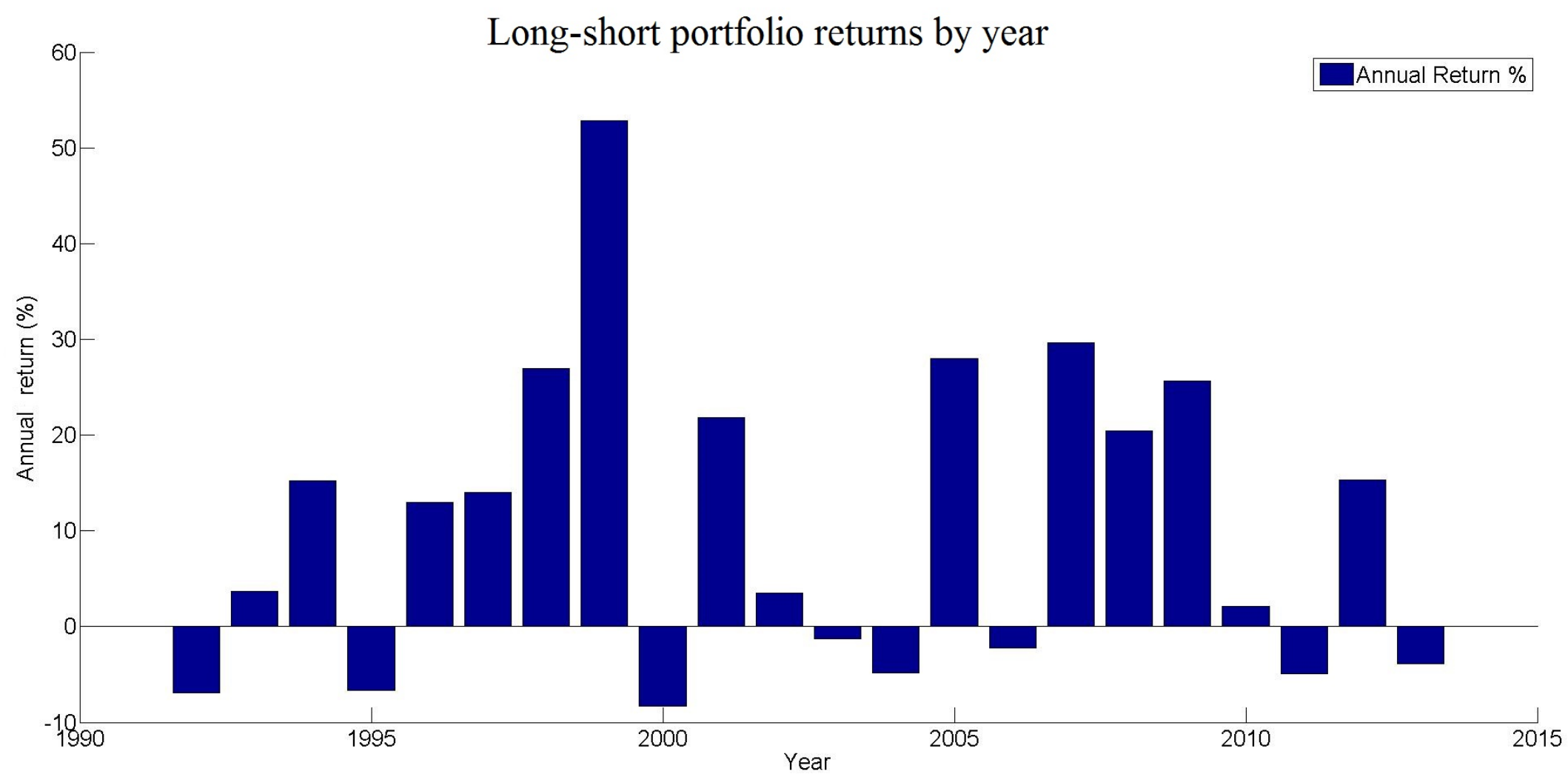

Figure 3: Returns to $\beta_{\% \Delta r_{\text {LIBORIM }}}$ strategy by year

The figure plots the annual returns for each year to the long-short portfolio from Table 6 . The sample excludes financial firms and covers 01/1992 - 12/2013. 

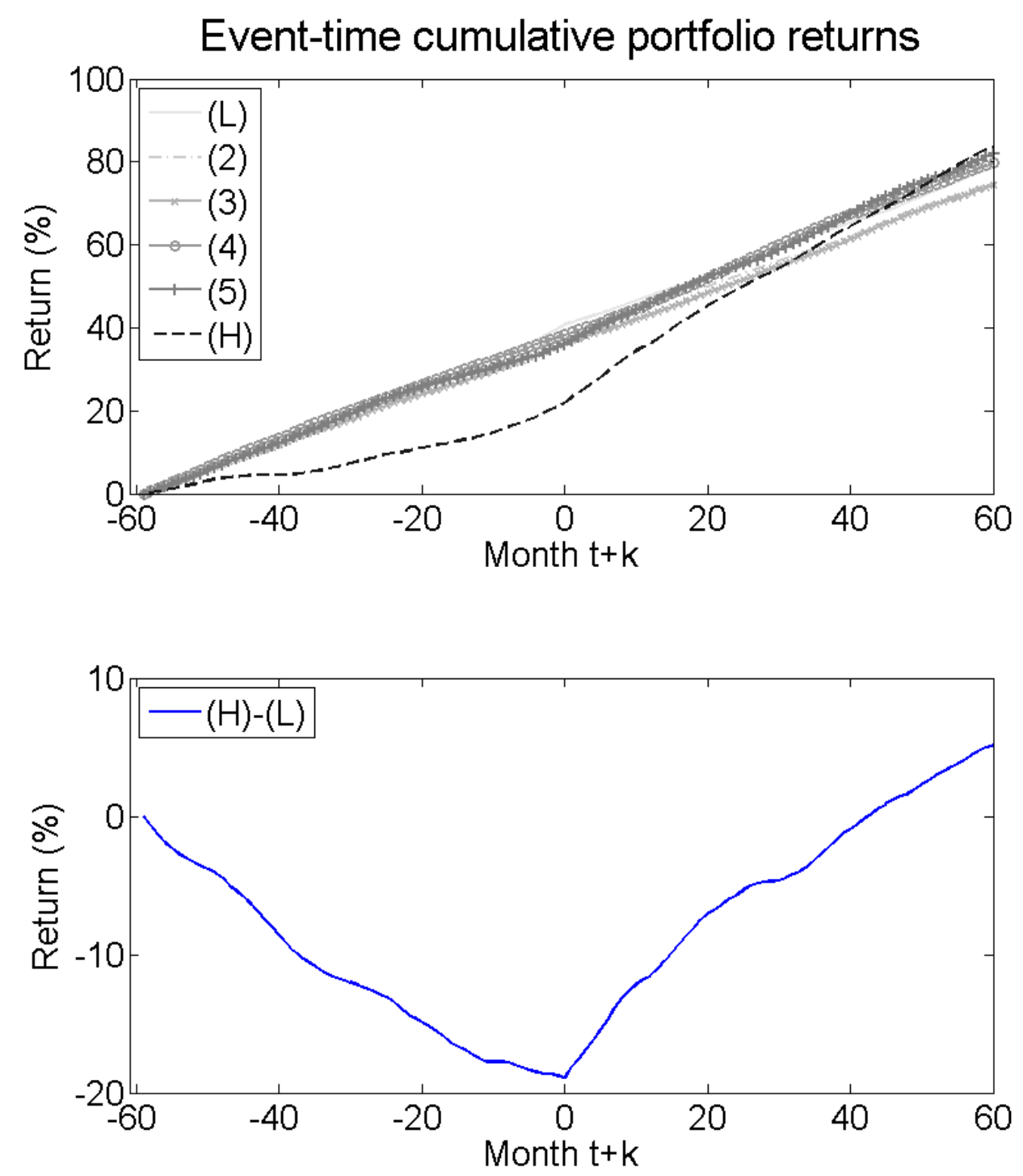

Figure 4: Event-time monthly portfolio returns

The figures plot average cumulative returns in event time for the six portfolios from Table 6 (top panel) and for the portfolio that is long stocks in portfolio six and short stocks in portfolio one (bottom panel). Time zero is the portfolio formation period. The sample excludes financial firms and covers 02/1991 - 12/2013. 

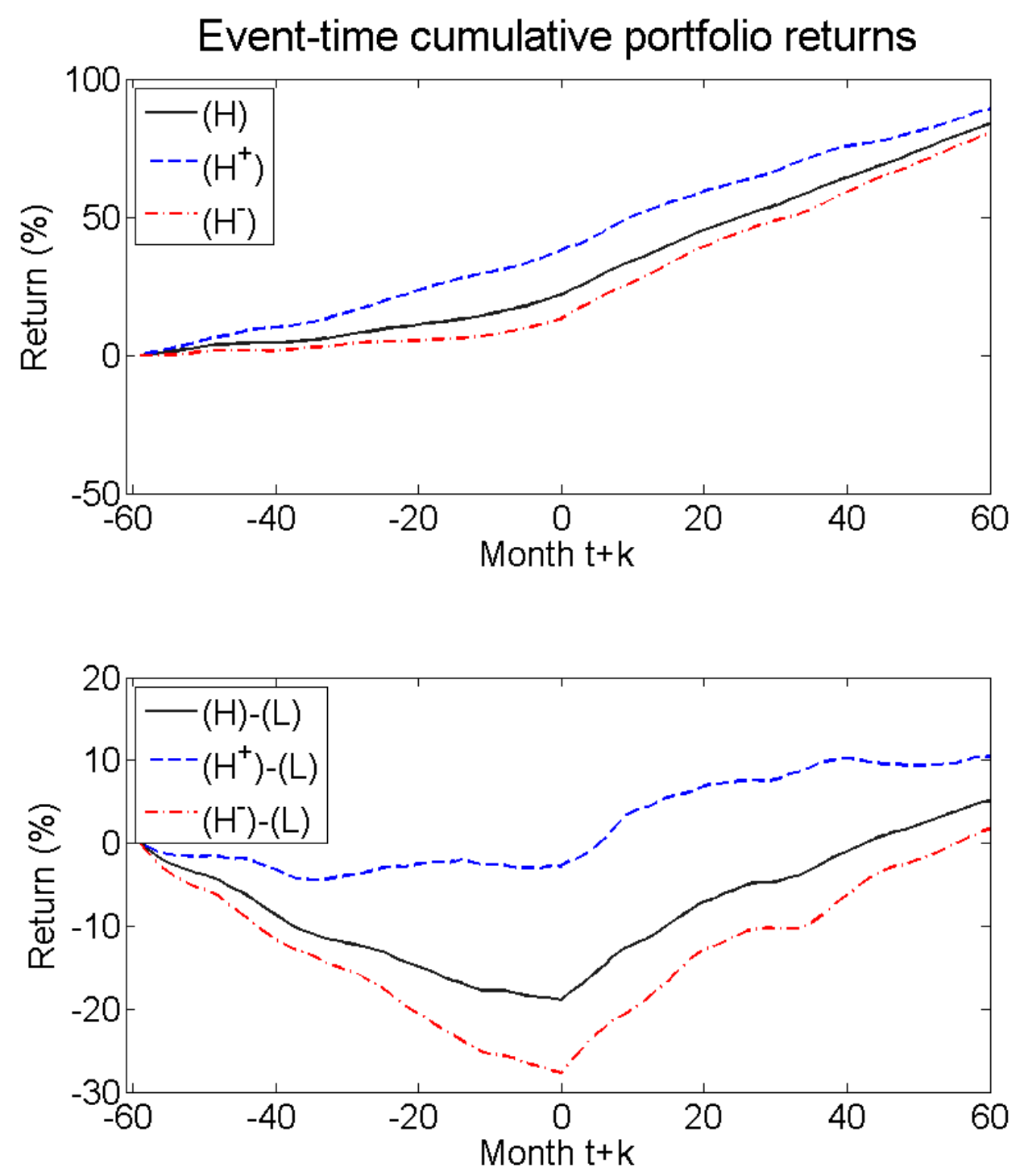

Figure 5: Event-time monthly portfolio returns for the highest $\beta_{\% \Delta r_{\text {LIBORIM }}}$ portfolio At the end of each month, stocks in portfolio $(\mathrm{H})$ from Table 6 are split into two bins, based on the difference in ranks in sorts on $\beta_{\% \Delta r_{\text {LIBORIM }}^{+}}^{+}$and $\beta_{\% \Delta r_{\text {LIBOR IM }}^{-}}^{-}$, where $\beta_{\% \Delta r_{\text {LIBOR IM }}^{+}}^{+}$and $\beta_{\% \Delta r_{\text {LIBOR IM }}}^{-}$are estimated as $\beta_{\% \Delta r_{\text {LIBORIM }}}$, but only using positive and negative LIBOR changes, respectively. $\left(H^{+}\right)$ denotes the portfolio consisting of firms in portfolio $(\mathrm{H})$ that have a relatively high $\beta_{\% \Delta r_{\mathrm{LIBOR} \text { IM }}}^{+}$, while $\left(H^{-}\right)$denotes the portfolio consisting of firms in portfolio $(\mathrm{H})$ that have a relatively high $\beta_{\% \Delta r_{\text {LIBORIM }}}^{-}$. The figure plots average cumulative returns in event time for the three portfolios individually (top panel) and a long-short portfolio that is long stocks in one of the three portfolios and short stocks in portfolio (L) from Table 6 (bottom panel). Time zero is the portfolio formation period. The sample excludes financial firms and covers 02/1991 - 12/2013. 

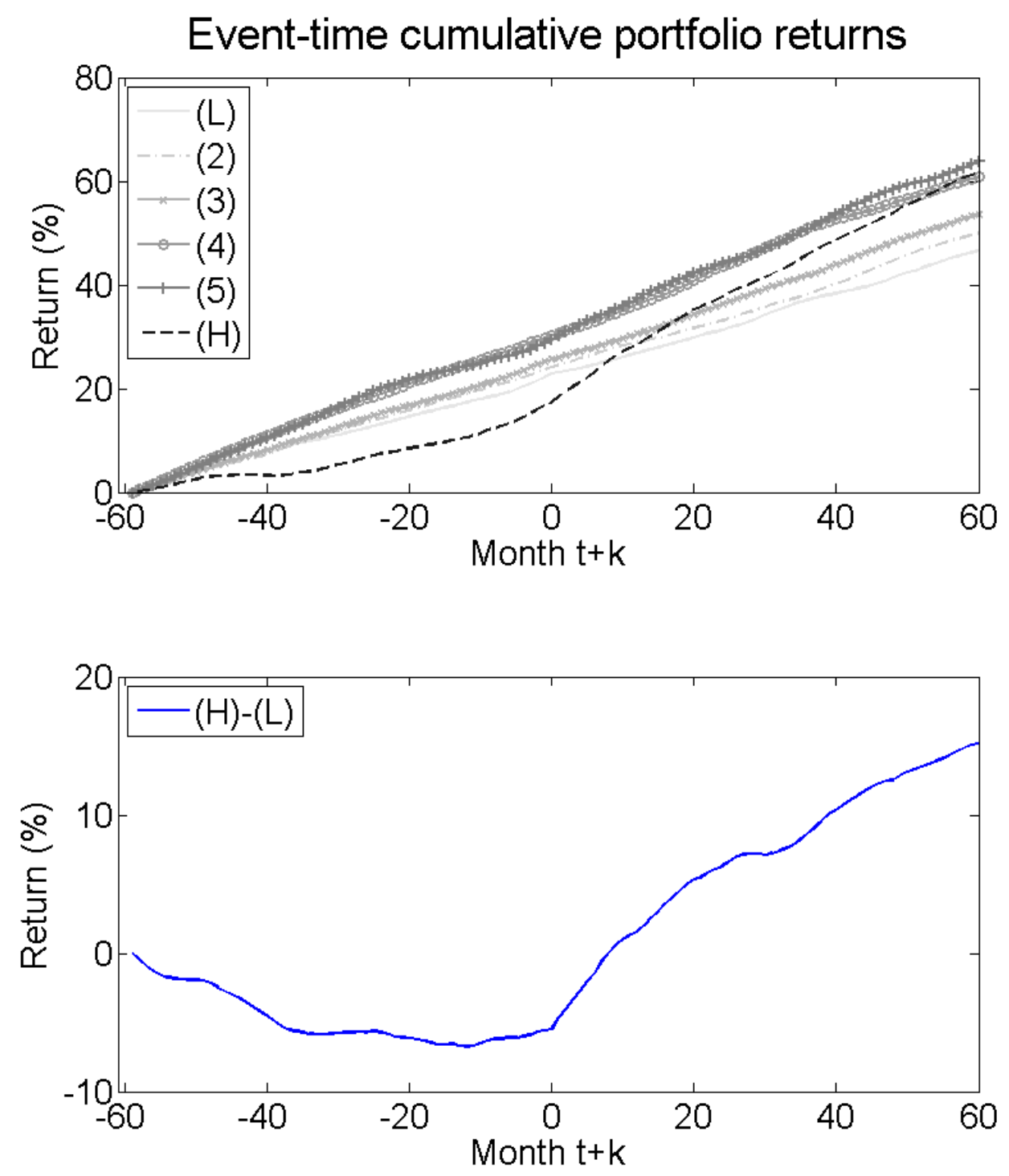

Figure 6: Event-time monthly portfolio returns excluding surprise rate cuts

The figures plot average cumulative returns in event time for the six portfolios from Table 6 (top panel) and for the portfolio that is long stocks in portfolio six and short stocks in portfolio one (bottom panel). The monthly returns used for the averages are cumulated from the daily returns on the CRSP tape by excluding the 3 days surrounding each of the 78 FOMC meetings with surprise rate cuts, identified following Kuttner (2001). Time zero is the portfolio formation period. The sample excludes financial firms and covers 02/1991 - 12/2013. 